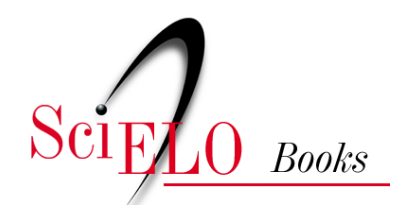

\title{
2. A formação do know-how (1938-1961)
}

\author{
Drielli Peyerl
}

\section{SciELO Books / SciELO Livros / SciELO Libros}

PEYERL, D. A formação do know-how (1938-1961). In: O petróleo no Brasil: exploração, capacitação técnica e ensino de geociências (1864-1968) [online]. São Bernardo do Campo, SP: Editora UFABC, 2017, pp. 86-145. ISBN 978-85-68576-78-6. https://doi.org/10.7476/9788568576786.0005.

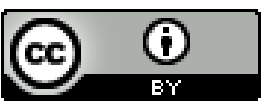

All the contents of this work, except where otherwise noted, is licensed under a Creative Commons Attribution 4.0 International license.

Todo o conteúdo deste trabalho, exceto quando houver ressalva, é publicado sob a licença Creative Commons Atribição 4.0.

Todo el contenido de esta obra, excepto donde se indique lo contrario, está bajo licencia de la licencia $\underline{\text { Creative }}$ Commons Reconocimento 4.0. 


\section{2}

A FORMAÇÃO DO KNOW-HOW

$(1938-1961)$






\section{1 - o trabalho de brasilleiros e estrangeitos para a formação da indústria petrolífera no Brasil}

Em 1937, na Argentina, já havia sido atingido o consumo interno graças à atividade da empresa estatal Yacimientos Petroliferos Fiscais; no Uruguai ocorria a inauguração da refinaria Teja; no México, acontecia a famosa crise petrolífera com os Estados Unidos; e, na Bolívia, um ano antes, uma empresa estatal fora criada para expropriar a Standard Oil Company do território (MARTINS, 1976, p. 288). Paralelamente a esses acontecimentos, no Brasil, ainda se discutia acerca da existência de petróleo, com a concentração dos esforços de técnicos e de empresários no controle da sua exploração e do seu refino (extremamente precário e com um oligopólio que controlava a importação e a distribuição de combustíveis) (MARTINS, 1976, p. 288-289).

Para Gabriel Cohn, na sua obra Petróleo e Nacionalismo, de 1968, no final da década de 1930, o Brasil vivia sob a política do Estado Novo (1937-1945); no panorama internacional, o início da II Guerra Mundial (1939-1945) preocupava os setores militares do governo Vargas; e, no plano da economia nacional, observava-se um impulso industrializante e de expansão da rede rodoviária. Esses são considerados pelo referido autor como impulsionadores do setor público na tomada de atitudes para solucionar os problemas que envolviam a questão do petróleo. 
A esses fatores, acrescentamos mais dois que contribuíram para tal atitude: a) a expropriação de todas as companhias estrangeiras e a nacionalização do petróleo mexicano em 1938 (influência essa significativa não somente no Brasil, mas na América Latina inteira); e b) a repercussão da publicação do memorial O Petróleo e a Defesa Nacional (1936), pelo General Júlio Horta Barbosa (1881-1965) ${ }^{86}$, destinado ao ministro da Guerra e General Eurico Gaspar Dutra (1883$1974)^{87}$, no qual aquele pede atenção ao problema petrolífero e critica-se as 'tímidas explorações' para obtenção de petróleo, afirmando que:

Sem petróleo, nosso potencial militar é baixo; sem petróleo, assistimos tristemente à penetração constante e ininterrupta da Standard Oil, da Royal Dutch Shell, Mexican Éagle, pelos menores recantos de nossa pátria. Hoje, pois substituir esses nomes por nomes brasileiros. Nutrimos fundas esperanças de que tal substituição ocorrerá, tanto mais cedo, quanto maior for a eficácia da cooperação do exército nas pesquisas para localização das fontes daquele combustível (A QUESTÃO..., 1979, p. 3).

${ }^{86}$ Militar e sertanista brasileiro. Formou-se em Engenharia e bacharelou-se em Matemática e Ciências Físicas. Exerceu a presidência do Clube Militar entre julho de 1936 e janeiro de 1937, onde se envolveu no debate sobre a existência ou não de petróleo no subsolo brasileiro. Foi presidente do CNP de 1938 a 1943. Notabilizou-se como defensor do monopólio estatal do petróleo e aderiu à Campanha do Petróleo. Horta Barbosa sempre participou da luta dos setores nacionalistas que permitiram a criação, em 1953, da Petrobras.

${ }^{87}$ Militar brasileiro e décimo sexto Presidente do Brasil. Participou ativamente da instauração do Estado Novo. Venceu as eleições para a presidência da República em 1945, assumindo o governo em 31 de janeiro de 1946, deixando o governo em 31 de janeiro de 1951. 
Pressionou-se, então, o governo brasileiro para a criação de um órgão próprio na questão do petróleo, pois as baixas condições de exploração por iniciativas particulares e governamentais persistiam, destacando-se a "impossibilidade de raros técnicos se especializarem no estrangeiro, [...] equipamentos em descompassos com as necessidades operacionais, [...] e a geologia hostil das bacias sedimentares" (MOURA; CARNEIRO, 1976, p. 225).

Em 29 de abril de 1938 ocorre a promulgação do Decreto-Lei $n^{\circ} 395$, que declara "de utilidade pública e regula a importação, exportação, transporte, distribuição e comércio de petróleo bruto e seus derivados, no território nacional, e bem assim a indústria de refinação de petróleo importado ou produzido no país" (COHN, 1968, p. 50). No seu artigo 4으, esse ato normativo criou o Conselho Nacional do Petróleo (CNP). Tem-se, então, a primeira atitude de nacionalização da indústria de refino do petróleo no país. Ainda no preâmbulo desse Decreto-Lei, está ressaltado:

[...] que essas medidas são tomadas "considerando que o petróleo constitui a fonte principal de energia para a realização do transporte, especialmente aéreo e rodoviário, serviço de utilidade pública nacional, indispensável à defesa militar e econômica do país" e "considerando a convivência de ordem econômica de prover a distribuição em todo o território nacional de petróleo e seus derivados em condições de preço tão uniformes quanto possível" (COHN, 1968, p. 50).

Logo em seguida, em 07 de julho de 1938, o Decreto-Lei n 538 organiza o então criado CNP, definindo suas atribuições e dividindo-o em "um órgão deliberativo (o Conselho Pleno) e em órgãos técnicos e administrativos" (COHN, 1968, p. 58). Assim, estava incumbido agora somente ao CNP 
a responsabilidade por controlar e autorizar a pesquisa, a exploração, a importação, a exportação, o transporte, a distribuição e o comércio de petróleo e seus derivados. Em relação às refinarias, cabia ao CNP autorizar a instalação (somente para brasileiros) e ainda fiscalizar o funcionamento de qualquer delas. Ou seja, o órgão assumia "todas as responsabilidades da indústria petrolífera, traçando as linhas gerais do que seria uma política de petróleo no País" (A QUESTÃO..., 1979, p. 3).

Esse período, que vai desde a promulgação até a execução dos Decretos-Leis referidos, é muito bem definido, na obra Em busca do petróleo brasileiro, de 1976, de Pedro de Moura e Felisberto Carneiro, como um "divisor de águas", pois, a partir desse momento, a política do petróleo passou a ter autonomia administrativa e financeira para traçar seu próprio caminho. Essa autonomia foi firmada pelo Decreto-Lei $\mathrm{n}^{\circ}$ 1.143, de 09 de março de 1939 (BRASIL, 1939), e era visível quando comparada à situação de flexibilidade no manejo de verbas entre o CNP e o Departamento Nacional de Produção Mineral, sendo a do CNP bem maior (DIAS; QUAGLINO, 1993, p. 14).

O início do trabalho pelo CNP foi cercado de inúmeros problemas já conhecidos e acumulados durante as várias tentativas de exploração do petróleo desde o final do século XIX, como apontado na primeira parte deste livro. As principais dificuldades técnicas encontradas estavam centradas em quatro itens:

a) Extensão e complexidade do território a explorar, agravadas pelas distâncias aos principais centros urbanos do país, deficiência de vias de comunicação, falta de recursos locais agravados, algumas vezes, pela existência de endemias tropicais.

b) Precariedade das cartas geográficas e geológicas, já disponíveis, do País. 
c) Desconhecimento quase completo das condições estruturais (tectônica) do subsolo a explorar.

d) Carência generalizada de técnicos e de mão-de-obra (TÁVORA, 1955, p. 73-74).

A contribuição parcial para a solução dos itens $a, b$ e $c$ surgiu com a elaboração de um mapa que descrevia, em gradação, as áreas com possibilidades de ser encontrado petróleo no Brasil, publicado em 1938 por Avelino Inácio de Oliveira, consoante os conhecimentos geológicos da época (ABREU, 1948, p. 137). Esse mapa serviu de base para o início das pesquisas do CNP. Além disso, por meio da flexibilidade de verbas destinadas ao CNP anteriormente mencionada, permitiu-se:

[...] por exemplo, a contratação de firmas prestadoras de serviços como as norte-americanas Drillig and Exploration Co. encarregada da perfuração dos poços, e United Geophysical Co. Não dispondo de técnicos ou equipamentos em número desejado, o CNP conseguira, com esses contratos, acelerar o ritmo dos trabalhos. Foi possível até mesmo adquirir três sondas modernas, ainda em 1940. No entanto, quando as restrições ao embarque de equipamentos de exploração e de peças de reposição foram impostas pelo governo norte-americano, não houve alternativa senão diminuir o ritmo das atividades (DIAS; QUAGLINO, 1993, p. 14 ).

Tanto fatos externos como internos afetaram o ritmo de pesquisa do CNP. Tentando amenizar a dificuldade descrita no item $d$, uma das medidas tomadas foi transferir técnicos e equipamentos do DNPM para o CNP, o que ocorreu por meio do Decreto $\mathrm{n}^{\circ} 1.369$, de 23 de julho de 1939 (DIAS; QUAGLINO, 1993). Essa atitude estava conectada às ordens 
do primeiro presidente do $\mathrm{CNP}^{88}$ nomeado pelo Presidente da República, Júlio Horta Barbosa, o qual permaneceu no cargo até 1943. A política de Horta Barbosa, conhecido por sua postura nacionalista, refletiu-se em três planos distintos: a) o da eliminação de atividades privadas do tipo wild-cat; b) o da regulamentação do mercado de combustíveis; e c) o da criação de refinarias estatais (MARTINS, L., 1976, p. 301).

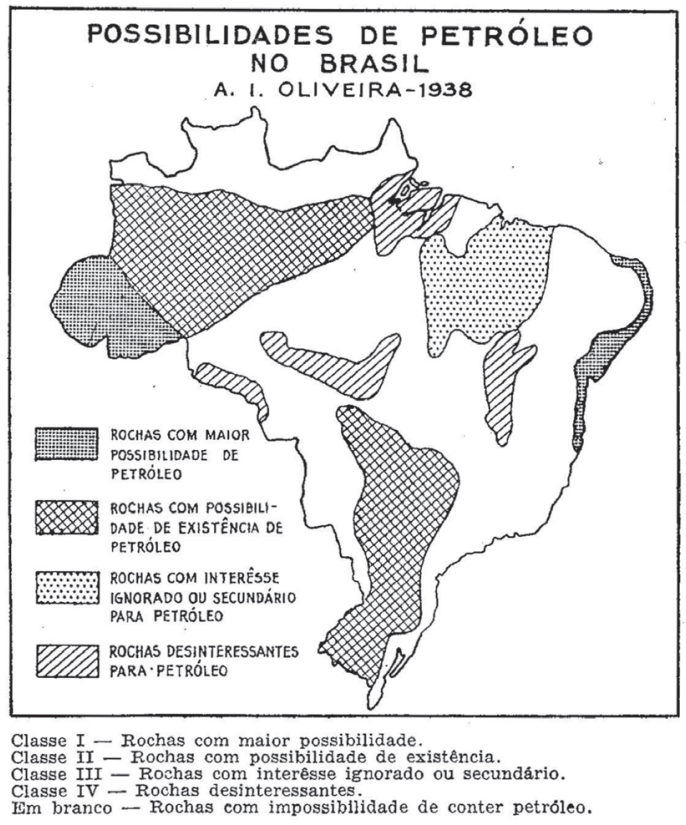

FIGURA 5. Possibilidades de petróleo no Brasil (1938)

Fonte: ABREU, 1948, p. 137

\begin{abstract}
${ }^{88}$ Para assumir o cargo de presidente do CNP era necessário: a) ser brasileiro nato, de notória competência e de reputação ilibada, além de ser maior de trinta anos de idade; b) estar no gozo de seus direitos civis e políticos; c) não ter, no momento da designação, nem ter tido nos cinco anos precedentes, interesses diretos ou indiretos em empresas particulares que se dediquem ou que hajam se dedicado à pesquisa, lavra, industrialização ou comércio do petróleo e seus subprodutos (BRASIL, 1938).
\end{abstract}


Outro motivo que levou o CNP a tomar iniciativas referentes à falta de mão de obra ou equipamentos foi a descoberta, em 21 de janeiro de 1939, de petróleo na região de Lobato na Bahia. Tanto que,

"entre 1940 e 1942, a Standard Oil fez três propostas para a criação de companhias mistas visando a pesquisa e extração, sendo rechaçadas pela oposição da cúpula militar, apesar da posição majoritariamente favorável do gabinete de ministros de Vargas" (BASTOS, 2006, p. 8).

Em abril de 1939, dois meses antes de o CNP entrar em atividade, Horta Barbosa centrou-se em visitar indústrias petrolíferas do Uruguai e da Argentina. A viagem levou-o a:

[...] recomendar que fosse enviado o maior número possível de técnicos aos países do Prata, para estudarem as especialidades da indústria petrolífera; que o CNP controlasse todas as atividades relativas à indústria; que fossem solicitados conselheiros à Argentina; que a refinação se tornasse monopólio estatal; e que fossem alocadas mais verbas ao CNP. ${ }^{89}$

Além disso, o CNP, sob ordem de Horta Barbosa, encomendou dos Estados Unidos "um conjunto completo de maquinaria” (MOURA; CARNEIRO, 1976, p. 230), investindo na modernização de equipamentos ("aquisição de três sondas rotatórias, isto é, duas a vapor, com capacidade para 2500 metros, e uma a diesel, para 1800 metros" (MOURA; CARNEIRO, 1976, p. 230), sendo estas destinadas aos Estados de Alagoas e Bahia). "Especialistas americanos treinariam os brasileiros

${ }^{89}$ Informações retiradas de CÂMARA DOS DEPUTADOS, 1939 apud SMITH, 1978, p. 53. 
no funcionamento das máquinas, que trabalhariam vinte e quatro horas por dia" (SMITH, 1978, p. 54).

O CNP também anunciou que contrataria empresas estrangeiras e especializadas em perfuração, o que se efetivou a partir de 1940 por meio da contratação da Drilling and Exploration Co. (Drillexco), de Los Angeles (EUA), que teve como proposta/obrigação a "de treinar os técnicos nacionais que estivessem participando em suas equipes" (MOURA; CARNEIRO, 1976, p. 230). Ressalta-se que nem todos os técnicos que participavam do treinamento permaneciam no CNP.

O CNP ainda investiu em empresas de geofísica estrangeiras para a prospecção sísmica, contratando, por exemplo, a United Geophysical Co. S.A., de Pasadena, Califórnia (EUA). Os serviços dessas empresas iam além da investigação local, contribuindo também com o treinamento de brasileiros participantes (MOURA; CARNEIRO, 1976, p. 230).

Nesse período, o investimento em refinarias, como observou Horta Barbosa em visita às refinarias do Uruguai e da Argentina, era de extrema importância, pois o lucro potencialmente elevado da refinação poderia financiar o desenvolvimento da pesquisa do petróleo. Por isso, o governo, como mencionado por Pedro de Moura e Felisberto Carneiro, "namorava" a siderurgia concentrando sua atenção na construção de uma usina siderúrgica (MOURA; CARNEIRO, 1976; SMITH, 1978; COHN, 1968). A saída encontrada, então, foi trabalhar para que a indústria de refinação e a pesquisa do petróleo pudessem ser financiadas de dentro da própria indústria do petróleo (SMITH, 1978).

Claramente observamos que a nacionalização do petróleo caminhava para o privilégio exclusivo de exploração de poços de petróleo e para os lucros adquiridos pela indústria de refinação, sem esquecer que a presença de estrangeiros era essencial para a construção de um know-how brasileiro. 
Apesar das leis e iniciativas criadas para tentar resolver as questões relacionadas ao petróleo desde a criação do CNP, o primeiro relatório oficial, de 1944 (publicado em 1946), faz menção aos mesmos problemas enfrentados desde o início pelo órgão: operando "durante os seus primeiros anos com falta ou inadequação de equipamento; com pessoal insuficiente, [...] e encontram-se numerosos exemplos de desperdício de tempo, equipamento e dinheiro" (COHN, 1968, p. 59). As críticas que perpassavam os anos, desde a criação do CNP, na maioria das vezes, estavam relacionadas à não permissão para que capitais estrangeiros participassem das sondagens e da exploração de petróleo. Ou seja, o Brasil poderia contratar e manter em suas mãos o controle da situação, mas não se abrir aos investimentos externos.

A passos longos, o CNP fazia "tanto o uso da experiência estrangeira quanto permitia o sentimento nacionalista", o que foi positivo para a eficaz pesquisa do petróleo (SMITH, 1978, p. 55). Porém, essas críticas estavam longe de se encerrar, principalmente quando as discussões remontavam à instalação de empresas estrangeiras ou à criação de uma companhia mista de capital nacional e estrangeiro para realizar o trabalho de sondagens, de abertura de poços, de produção de petróleo e de fornecimento de técnicos (SMITH, 1978).

O período de regulamentação e de decisões apresentadas pelo CNP, principalmente de 1939 até 1943, deixa nítidas as oscilações de abertura para a participação e/ou contratação de empresas estrangeiras - como às já citadas United Geophysical Co. e Drilling and Exploration Co. - em num país que tinha como viés o nacionalismo, mas que necessitava do know-how de outros países para avançar na exploração e na prospecção do petróleo. De acordo com Smith, "para muitos, 
devia parecer inacreditável que um país tão desesperadoramente necessitado de combustível recusasse com tanto vigor a ajuda técnica especializada estrangeira, que poderia acelerar a descoberta de fontes nacionais de petróleo" (SMITH, 1978, p. 60).

É o que o novo Presidente do CNP, em 1943, tenta mudar. 0 Coronel do Exército João Carlos Barreto (1895-1970) "estava mais interessado no rápido desenvolvimento do petróleo do que na manutenção de controles nacionalistas sobre a nascente indústria", sendo abertamente receptivo à ideia da participação estrangeira na descoberta de petróleo (SMITH, 1978, p. 61) - tanto que acrescentou, no Relatório de 1944:

Preocupava-nos muito a formação de um grupo de técnicos brasileiros especializados não só na geologia do petróleo, como em todos os ramos da prospecção e exploração.

Daí estabeleceu-se que em todos os contatos com empresas ou técnicos estrangeiros, para execução de serviços especializados, devia constituir condição essencial e imperativa a formação da nossa gente, no mais breve prazo, por isso que, de futuro, lhe caberia a responsabilidade da condução técnica desse problema vital na economia do País. Concomitante, cuidamos de recrutar para o Conselho maior número de profissionais brasileiros, para atuarem ao lado dos técnicos norte-americanos contratados, de sorte a tornar-se mais praticável a seleção desejada (MOURA; CARNEIRO, 1976, p. 244).

Fatores externos ainda modificariam as iniciativas do CNP, pois muito do material necessário para o trabalho de campo e para o início das explorações eram de difícil aquisição no exterior por conta da II Guerra Mundial (1939-1945). 
Porém, acrescentamos a esse fato o de que, mesmo no período mais crítico da guerra (1941-1942), "a participação no setor industrial no produto global não deixou de crescer”, e, após o conflito, apresentou um avanço notável (COHN, 1968, p. 74). O Brasil também aproveitou esse período para a contratação de técnicos e de geólogos, bem como para "pôr ao lado deles, para cada geólogo estrangeiro [contratado], dois técnicos nacionais para se formarem" (MOURA; CARNEIRO, 1976, p. 230).

Outro evento, internamente impulsionador neste estudo, ocorre a partir de 1945, quando os investimentos para treinamento prático dentro do CNP, em diversas áreas, ganham uma atenção relevante e diretamente relacionada às atividades de exploração de petróleo. Essas atividades concentram-se em sondadores, operadores de patrola, motoristas de caminhões pesados e pilotos de embarcações, manipuladores de cargas de dinamite, interpretadores de fotografias aéreas, desenhistas, mecânicos, operadores de sismógrafos e tantos outros tipos de mão de obra relacionada à pesquisa de petróleo (MOURA; CARNEIRO, 1976, p. 245).

Para suprir essa necessidade de mão de obra, o CNP investia cada vez mais na contratação de profissionais estrangeiros para responder ao treinamento de brasileiros. As empresas estrangeiras contratadas para a exploração do solo brasileiro, além de receberem pelos seus serviços, ainda exigiam do CNP boas condições para a realização do trabalho, como "estradas de acesso, acampamentos, pontes, movimentação de terra, admissão de pessoal para os mais diversos misteres, ajustes de empreiteiros etc" (MOURA; CARNEIRO, 1976, p. 249). Caso essas condições não fossem possíveis, a empresa estrangeira tomaria a frente e executaria as melhorias necessárias, mas o CNP teria que arcar com qualquer custo além do já estabelecido. As empresas estrangeiras que 
aqui se fixavam em conjunto com o CNP moviam cerca de 1.500 funcionários (MOURA; CARNEIRO, 1976).

A maioria das empresas estrangeiras que se instalaram por meio de contrato com o CNP treinaram engenheiros em determinadas áreas como, por exemplo, em perfuração. Enquanto isso, outros brasileiros pertencentes ao CNP se especializavam no exterior, principalmente nos Estados Unidos, em engenharia de petróleo e geologia.

Entre 1945 e 1950, o Brasil passou por um período de intensa revisão política de nacionalismo econômico, aderindo à contratação de um maior número de "técnicos estrangeiros para ajudar tanto na elaboração de diretrizes como no treinamento de brasileiros" (SMITH, 1978, p. 60). Porém, esses treinamentos ainda tinham um caráter meramente prático, e não de aperfeiçoamento ou de profissionalização certificada.

Em meados da década de 1940, Sylvio Fróes Abreu apontou que "o isolamento dos técnicos brasileiros agiria como freio sobre a pesquisa e a lavra do petróleo brasileiro, e a falta de contacto com geólogos estrangeiros redundara em que os métodos brasileiros estavam atrasados" (SMITH, 1978, p. 64). Por mais que já houvesse um posicionamento do CNP perante essa situação - pois este estava buscando técnicos estrangeiros para treinar brasileiros ou enviando parte de seus técnicos brasileiros para se especializar no exterior -, isso não foi suficiente para acalmar os ânimos de nacionalistas e entreguistas ${ }^{90-91}$ que esperavam pelas notícias de poços de petróleo produtores.

\footnotetext{
90 Questões relacionadas ao petróleo que deveriam ser resolvidas mediante atração do capital estrangeiro.

91 Juarez Távora, político e militar brasileiro, ficou conhecido como entreguista em relação à exploração de petróleo no Brasil. Foi a favor da entrega de recursos naturais para exploração de empresas e de instituições estrangeiras, opondo-se às questões nacionalistas da época. Foi o principal líder dos que se opunham à criação da Petrobras.
} 
O Conselho Nacional do Petróleo revelava-se, assim, falho nas atividades cotidianas, afetadas ao setor técnico e à administração corrente. Sua importância era melhor demonstrada na tomada das "grandes decisões", para as quais, na realidade, êle havia sido concebido, mais do que para a ação rotineira.

É, portanto, na área das decisões que afetam de modo global a economia do país e dizem respeito às grandes linhas da política do petróleo que a ação do CNP deixou suas marcas mais profundas (COHN, 1968, p. 61).

Em 1947, Sylvio Fróes de Abreu esboçou um mapa baseado no de Avelino Inácio de Oliveira, de 1938, o qual intitula de "Perspectivas do petróleo no Brasil", contribuindo para os estudos e pesquisas de petróleo no país. As contribuições de Fróes de Abreu ao mapa de Oliveira consistem nas "condições geológicas acrescidas dos conhecimentos novos", adquiridas no período, acrescentando a rápida evolução de métodos relacionados à pesquisa de petróleo mundialmente, bem como na introdução do "conceito de accessibilidade e distância aos centros de consumo" (COHN, 1968, p. 136).

Isso foi muito bem sintetizado por A. I. Levorsen ${ }^{92}$, quando organizou em 1942 um inquérito para consultar a opinião dos técnicos sôbre a melhor maneira de se descobrir óleo e gás nos Estados Unidos. Comentando o fato êle pôs em evidência a evolução do pensamento dos geólogos; em 1920, diz êle, a resposta seria indubitàvelmente: mais mapeamento de estruturas superficiais; em 1925 seria: mais ênfase nas condições subsuperficiais, e em 1930 seria: mais geofísica. Agora nós acrescentamos em 1947 seria: mais aerogeologia, mais sedimentologia e mais geoquímica (ABREU, 1948, p. 136).

${ }_{92}$ Arville Irving Levorse (1864-1965) foi um geólogo americano. 
No que diz respeito ao conceito de acessibilidade e distância aos centros de consumo presente no mapa elaborado por Fróes de Abreu, destaca-se a importância fundamental do transporte do petróleo. Esse é um problema essencialmente econômico, no que tange ao tratamento de poços comerciais e subcomerciais.

Note-se que um barril de óleo brasileiro, nos confins do Acre é menos valioso que um barril no Recôncavo ou na bacia do Paraná. Outro fator a ser considerado é o da accessibilidade da área às pesquisas. Isso depende em parte da distância aos centros civilizados e também da cobertura vegetal, da salubridade, clima da região e das condições geológicas particulares à área. Quinhentos metros de basalto sôbre uma área constituem um óbice quase insuperável com as técnicas em uso. Quem já fez explorações desse gênero sabe como pesam as despesas decorrentes da agressividade do meio ou do isolamento. A lentidão dos trabalhos, a necessidade dum almoxarifado bem provido, os gastos em alimentação, as medidas sanitárias e transportes elevam tanto o preço dos trabalhos que as condições geográficas da área passam a influir de maneira bastante sensível sôbre o custo do barril produzido (ABREU, 1948, p. 136).

No final da década de 1940 e no início da de 1950, mudanças no cenário político modificaram a economia do país. 0 governo Dutra adotou uma política econômica de abertura para as empresas multinacionais, estabelecendo um cenário político internacional e aumentando significativamente o número de importações. Para o economista Pedro Paulo Zahluth Bastos, a política econômica do governo Dutra pode ser descrita como um pêndulo, pois: 


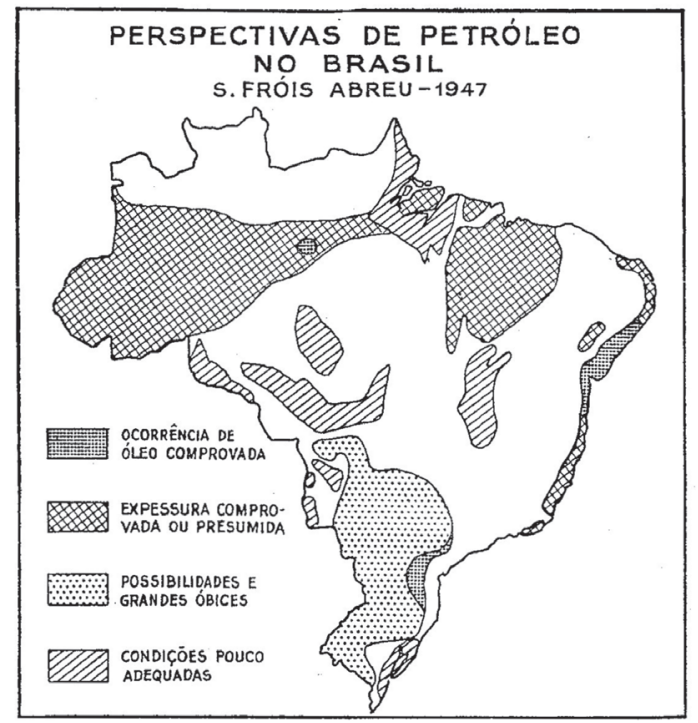

Classe I - Regióes com ocorrência comprovada.

Classe II - Regiōes com espessura comprovada ou presumida.

Classe' III - Regiós com possibilidades e grandes óbices.

Classe IV - Regiסes com condicoes pouco adequadas.

$\mathrm{Em}$ branco - Regiöes sem possibilidades de conter petróleo.

FIGURA 6. Perspectivas de encontrar petróleo no Brasil - 1947

Fonte: ABREU, 1948, p. 137

Inicialmente, a prioridade recaiu sobre um plano de estabilização inflacionária (limitação do gasto público, controle do crédito) apoiado em reformas liberais (abertura comercial e financeira) e estabilidade do câmbio nominal. 0 diagnóstico da inflação culpava heranças intervencionistas do Estado Novo, de maneira que controlar os preços exigia liberar mecanismos de mercado e limitar influências nocivas do governo. Aproximadamente em metade do mandato, uma crise cambial forçou o governo a voltar atrás na abertura comercial para defender reservas cambiais e resguardar importações essenciais, embora sem reverter a abertura financeira inicial. 0 governo procurou defender a taxa de câmbio limitando importações pouco essenciais, evitando o impacto inflacionário de uma 
depreciação cambial. Isto protegeu o mercado interno para a produção substitutiva de importações, que seguiu seu curso à medida que o governo procurava retirar "gargalos" (escassez de dividas, crédito e infraestrutura) que limitavam a expansão (BASTOS, 2004, p. 100).

Foi também durante o governo Dutra que foi promulgada a Constituição de 1946, momento em que ocorre uma maior nitidez dos interesses sociais na determinação da forma do Estado e no direcionamento da industrialização no país (DRAIBE, 2004). 0 artigo 153 dessa Constituição dispõe que "o aproveitamento dos recursos minerais e de energia hidráulica depende de autorização ou concessão federal na forma da lei" (BRASIL, 1946). O parágrafo primeiro desse artigo dispõe:

As autorizações ou concessões serão conferidas exclusivamente a brasileiros ou a sociedades organizadas no País, assegurada ao proprietário do solo preferência para a exploração. Os direitos de preferência do proprietário do solo, quanto às minas e jazidas, serão regulados de acordo com a natureza delas (BRASIL, 1946). ${ }^{93}$

\footnotetext{
93 "A preferência é entre pessoas que tenham a capacidade de direito de que cogita o art. 153, 1a parte (Brasileiro ou sociedade, pessoa jurídica brasileira, organizada no Brasil).

Sociedade organizada no Brasil mas que se ligue a direito estrangeiro (e.g., sejam pessoas jurídicas de direito estrangeiro, ou sejam filiais ou sucursais de sociedades estrangeiras) não pode ter mina ou explorá-la, porque a ratio legis do art. 152, 1a parte, da Constituição de 1946 foi afastar tôda possível ingerência de atuação externa. 0 capital pode ser estrangeiro; a sociedade há de ser organizada no Brasil e, pois, sòmente regida pelo direito brasileiro. [...]

As ações das emprêsas exploradoras de minas, riqueza do subsolo e quedas de água não podiam ser ao portador. Em nome coletivo, em comandita
} 
A esse artigo somava-se as ideologias constitucionalmente adotadas nas Constituições de 1934 e 1937 (COELHO, 2009).

Em 1947, por meio de uma comissão criada pelo presidente Eurico Gaspar Dutra, objetivou-se revisar as leis existentes referentes à exploração de petróleo no país e criar outras, como, por exemplo, o projeto de lei intitulado Estatuto do Petróleo. 0 projeto acirrou o debate entre nacionalistas e entreguistas. Caso o projeto fosse levado adiante, a nacionalização do petróleo se tornaria impossível, pois iria favorecer a abertura para o capital internacional. Associado a esse projeto estava a decisão do CNP "de abrir às empresas privadas a indústria da refinação de petróleo" (COHN, 1968, p. 106). Uma das principais justificativas para a abertura ao capital externo era a falta de técnicos especializados e as condições precárias em que o CNP se encontrava (COHN, 1968; SMITH, 1978).

Reagindo a esse projeto de lei, nacionalistas reunidos em conferências no Clube Militar lançam a Campanha do Petróleo, tendo como lema a frase "O petróleo é nosso". Essa campanha, que mobilizou militares, intelectuais, estudantes, imprensa, sindicatos e o Congresso Nacional, visava o controle nacional sobre o petróleo, defendia o monopólio estatal e trazia questionamentos sobre a exploração de petróleo e a influência estrangeira sobre o produto. "O discurso identificado com a corrente desenvolvimentista nacionalista do Clube Militar foi tão contundente que, em aliança com os civis,

simples, nenhum dos sócios podia ser estrangeiro, nem sociedade composta de estrangeiros, ainda que brasileira. Sociedade, ainda brasileira, para que pudesse ser acionista de alguma dêssas emprêsas, precisava ser composta por Brasileiros e sòmente por Brasileiros. Nenhum direito de sócio era alienável a estrangeiros" (MIRANDA, 1960, p. 524-525). 
levantou amplos setores da sociedade em defesa do petróleo" (ANDRADE, 1999, p. 81).

Um ponto a destacar em relação à Campanha do Petróleo, é que, no momento, não se discutia mais a existência de petróleo, questão essa que atravessou décadas de controvérsias e conflitos. Até então, poucos poços (e ainda em quantidade comercial baixa) estavam sendo explorados no país. "'0 petróleo é nosso' traduzia tão somente um anseio generalizado de irrestrita nacionalização da indústria petrolífera no País" (MOURA; CARNEIRO, 1976, p. 261).

Após dois meses da apresentação do Estatuto do Petróleo no Congresso Nacional, criou-se, em abril de 1948, o Centro de Estudos e Defesa do Petróleo, ${ }^{94}$ o qual passa a dirigir a Campanha do Petróleo no país, "articulando militares, estudantes, homens públicos e intelectuais" (PETROBRAS 50..., s.d.). 0 centro tinha como finalidade promover debates, conferências, artigos, entre outros, voltando-se para o fortalecimento nacionalista do monopólio estatal.

Após a difícil tramitação do projeto do Estatuto do Petróleo, este é arquivado. 0 governo Dutra passa a investir na criação de refinarias e na aquisição de uma frota nacional. Em 1950, criou-se a Frota Nacional de Petroleiros (FRONAPE) com o objetivo de "executar o transporte de petróleo e derivados no país e no estrangeiro, podendo ainda realizar a respectiva armazenagem e comércio" (BRASIL, 1950). No início, o CNP adquiriu para a FRONAPE vinte e dois navios-tanque.

94 Em 1949, passou a se chamar Centro de Estudo e Defesa do Petróleo e da Economia Nacional (CEPDEN). 


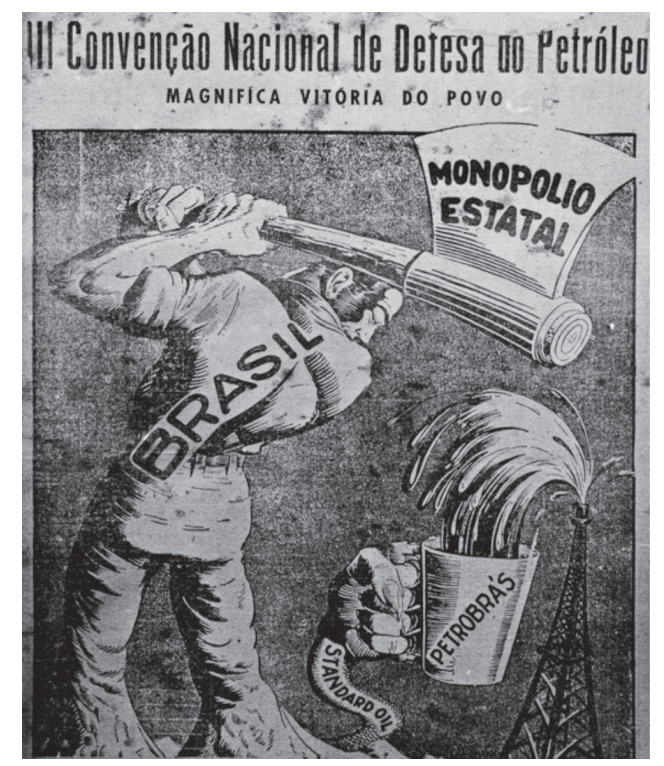

FIGURA 7. Cartaz da III Convenção Nacional de

Defesa do Petróleo, promovida pelo CEDPEN - 1952

Fonte: CARTAZ DA..., 1952

Outros dois projetos receberam fortes investimentos pelo CNP: a Refinaria de Mataripe e a Refinaria de Cubatão, ambas proporcionando pleno rendimento, sendo administradas como entidades industriais (VARGAS, G., 1964). Na década de 1950, durante a direção do CNP, realizaram-se estudos para a construção da Fábrica de Fertilizantes de Cubatão, "que mais tarde viria a fabricar no país o primeiro produto petroquímico básico, ou seja, a amônia anidra, utilizando os gases residuais da Refinaria Presidente Bernardes" (SEABRA, 1965, p. 119).

No que concerne ao aperfeiçoamento e à profissionalização, em 1952, o CNP adotou o que podemos considerar como uma das principais iniciativas de mudança de rumo 
para o ensino e para a pesquisa de petróleo no Brasil, e que apenas somou para o trabalho de formação de know-how brasileiro: Setor de Supervisão e Aperfeiçoamento Técnico (SSAT), que tinha como objetivo gerar mão de obra profissional e própria. Os detalhes desse processo serão visíveis na parte seguinte deste livro.

Antes de o CNP tomar tal decisão, as iniciativas em formar mão de obra no país - necessidade essa que procuramos demonstrar nas páginas anteriores - concentravam-se num plano secundário, inclusive relacionando-se à aplicação de verbas e a problemas que perpassavam as décadas. Ela era secundário no sentido da quantidade de demandas e pressões que beiravam a política e a economia do petróleo nacional e internacionalmente.

Na época, três soluções apresentavam-se, naturalmente, para ampliar o quadro de profissionais de nosso país, conforme classificação de Oliveira Júnior, moldada ao tema aqui apresentado: a) contratar técnicos estrangeiros; b) enviar jovens para estudar em escolas estrangeiras; e c) desenvolver o ensino no próprio país (OLIVEIRA JÚNIOR, 1959). Todas essas soluções foram absorvidas pelo CNP e, posteriormente, pela Petrobras, conforme demonstrado a seguir.

Cada ponto acima mencionado teria suas vantagens e desvantagens. Em relação ao ponto a), os custos eram dispendiosos (salários altos, dificuldades oriundas da diferença de línguas) e as técnicas empregadas pelos profissionais difeririam muito de um país para outro, ainda mais em se tratando dos termos utilizados na geologia. Temos também o problema que era trazer os estrangeiros para o país. Nessa toada, Oliveira Júnior classifica a falta de cientistas e de engenheiros como um fenômeno universal, utilizando da obra 
L'angoissante pénurie d'ingénieurs et téchniciens, de 1956, para justificar no caso da França: "0 número dos engenheiros e técnicos formados cada ano é notòriamente insuficiente. Os efetivos permanecem pràticamente os mesmos nestes últimos 35 anos, ao passo que as necessidades duplicaram ou triplicaram" (OLIVEIRA JÚNIOR, 1959, p. 49). A vantagem seria que, caso ocorresse a contratação de profissionais estrangeiros, esses poderiam ensinar as técnicas aos brasileiros para a formação de seu próprio know-how.

0 ponto $b$ ) demandava investimento além do orçamento destinado ao CNP para tal finalidade. Além disso, ao participarem de cursos, de especializações ou mesmo de uma formação completa no exterior (com tempo mínimo geralmente de seis meses), o país ficaria temporariamente sem essa mão de obra, que já era restrita, e não garantia permanência do profissional no CNP.

No que tange ao ponto $c$ ), os custos seriam muito além da somatória dos pontos $a$ ) e $b$ ), além do que seriam necessárias mudanças educacionais, econômicas e políticas dentro do país. De todos os níveis, este seria o mais difícil para se manter e colocar em prática, inclusive pela falta de profissionais para lecionar as matérias relacionadas aos estudos de petróleo (incluindo Geologia, Paleontologia, Engenharia, entre outros).

O CNP absorveu esses três pontos. Nos primeiros anos, o órgão concentrou-se mais nos pontos $a$ ) e b), e, em 1952, passou a investir no ponto $c$ ), momento que se descreve como a primeira atitude de formação de sua própria mão de obra e de incentivos para desenvolver e aprimorar sua técnica. Foi então que se iniciou a criação do SSAT, anteriormente mencionada. 
Para encerrar este tópico, não podemos deixar de utilizar as descrições acima e adiantar os pontos que a Petrobras absorveu. Esta investiu em todos os pontos, mas em escalas diferentes das do CNP, associando-os e compreendendo seus impactos nas estruturas de formação profissional do país, principalmente pelo ponto c). Ela contribuiu, assim, massivamente em setores e transformações do ensino do Brasil, principalmente na área de geociências, na construção e no desenvolvimento da técnica, na manutenção de seus próprios equipamentos e na formação de seu know-how.

\section{2 - a petrobras e a participaç̄ono de estrangeipos (1953-1961)}

Em 31 de janeiro de 1951, Getúlio Vargas chegou novamente à presidência, dessa vez pelo voto popular direto, e encontrou um Brasil bem diferente do qual tinha governado anteriormente. A estrutura de classe estava mais complexa do que aquela existente no Estado Novo, porquanto passou a ser movida principalmente pelos "processos gêmeos de industrialização e urbanização", os quais "tinham aumentado e fortalecido três setores: os industriais, a classe operária urbana e a classe média urbana” (SKIDMORE, 2010, p. 117). A meta do novo governo Vargas convergiu para a "industrialização acelerada enquanto condição do progresso social [...] e o Estado armou-se de novas instituições e instrumentos capazes de viabilizá-las" (MENDONÇA, 1990, p. 333).

No início da década de 1950, com a doutrina desenvolvimentista, surge no Brasil tecnologias necessárias para a consecução das metas de energia e transportes, as quais completam o quadro da tecnologia civil 
brasileira, atingindo níveis de notabilidade internacional (VARGAS, M., 1994, p. 24).

Assim, o governo Vargas (1951-1954), internamente, "enfatizou a necessidade de empresas estatais como instrumento básico de uma política de investimentos" (SKIDMORE, 2010, p. 132). Em dezembro de 1951, o governo levou ao Congresso Nacional o projeto de lei para a criação de uma empresa mista (público-privada) do petróleo, a qual deteria o "monopólio da exploração do petróleo e de todas as novas refinarias $^{95 "}$ (SKIDMORE, 2010, p. 132).

\section{UM GRANDE EMPREENDIAENTO ECONOMICO LANÇADO NO ERASIL \\ Visando solucionar o problema do p ctróleo, o Chefe do Govêrno envia mensagem ao Congresso Nacional propondo a organização de uma em- prêsa mista de capital público e privado para a industrializaç̃o dessa fonte de riqueza do Pais - A integra da mensagem presidencial}

FIGURA 8. Manchete do Jornal do Brasil de 07 de dezembro de 1951 Fonte: UM GRANDE..., 1951, p. 9

O debate sobre a política do petróleo, acirrado pela Campanha do Petróleo, dominava a atenção pública há décadas, intensificando-se a partir de 1945. 0 tema predominou no centro das discussões públicas, mais do qualquer outro assunto (SKIDMORE, 2010, p. 133), contribuindo para a criação dessa empresa de monopólio estatal.

Em 03 de outubro de 1953, por meio da Lei nํㅜ 2.004, criou-se a Petróleo Brasileira S.A. (sigla ou abreviatura:

\footnotetext{
95 "Embora as refinarias existentes tivessem permissão para permanecer nas mãos de empresas privadas, e a distribuição de produtos petrolíferos ficasse a cargo do setor privado" (SKIDMORE, 2010, p. 132).
} 
Petrobras), sociedade de economia mista que tinha por objeto a pesquisa, a lavra, a refinação, o comércio e o transporte do petróleo proveniente de poço ou de xisto de seus derivados, bem como de quaisquer atividades correlatas ou afins (BRASIL, 1953). Com essa mesma Lei, o petróleo foi monopolizado ${ }^{96}$ como bem da União "por meio do Conselho Nacional do Petróleo, como órgão de orientação e fiscalização", e "por meio da sociedade por ações da Petrobras e de suas subsidiárias, constituídas na forma da presente lei, como órgãos de execução" (BRASIL, 1953).

Para Luciano Martins, esse momento é considerado um campo fértil para a análise da dinâmica dos atores e de suas ideologias durante uma fase de complexa reorientação política da sociedade, pois, para ele, a nacionalização do petróleo

96 "A monopolização, essa, sòmente pode resultar de invocação do art. 146 [da Constituição Federal de 1946], onde se diz: 'A União poderá, mediante lei especial, intervir no domínio econômico e monopolizar determinada indústria ou atividade. A intervenção terá por base o interêsse público e por limite os direitos fundamentais assegurados nesta Constituição'.

Pode haver monopolização, pela União, da propriedade do solo antes de qualquer autorização. Pode haver monopolização, pela União, da propriedade do solo, depois e independente do direito de exploração. Pode haver monopolização, pela União, de ambos os direitos ou sòmente do direito de exploração, a ser exercido ou já com as indústrias instaladas, ou instaladas e em andamento.

A Lei n. 2.004, de 3 de outubro de 1953, enumerou as atribuições do Conselho Nacional do Petróleo e criou a Petrobrás . Tal lei sòmente podia ser feita com invocação, explícita ou implícita, do art. 146 da Constituição de 1946, uma vez que, no art. 1ำ, estabeleceu: 'Constituem monopólio da União: I. A pesquisa e a lavra das jazidas de petróleo e outros hidrocarbonetos fluidos e gases raros, existentes no território nacional. II. A refinação do petróleo nacional ou estrangeiro.'

[...] A Lei n. 2.004 criou o monopólio (art. $1^{\circ}$ ) e podia, diante da Constituição de 1946, criá-lo" (MIRANDA, 1960, p. 523). 
não pode ser confundida com a ascensão ao nacionalismo, mas sim com seu declínio. A partir da segunda metade de 1950, o nacionalismo tornou-se mais um fenômeno de reação, como um projeto e um instrumento de mobilização, ou seja, por meio dele buscou-se o controle da nação contra o imperialismo. Esse papel que o nacionalismo exerceu, nesse período, facilitou a implementação de um projeto de desenvolvimentismo (MARTINS, 1976). A concretização política e econômica desse projeto ocorreu no governo de Juscelino Kubitschek (1956-1961), em que se registrou notável crescimento econômico, principalmente após a ampliação da produção industrial.

Destaca-se, ainda, que a criação da Petrobras com base em investimento estatal (mesmo que de economia mista, pois nesta o controle majoritário sempre é da União) não é pioneira no Brasil, podendo ser citados alguns outros exemplos: a Companhia Siderúrgica Nacional (1941), a Companhia Vale do Rio Doce (1942), a Companhia Nacional de Álcalis (1943) e a Companhia Hidrelétrica do São Francisco (1945).

Em um ritmo acelerado, com orçamento maior que o do CNP, a Petrobras deparou-se com "um problema de consideráveis dimensões - a falta de pessoal especializado para operar todo esse complexo industrial" (FORTES, 2003, p. 2), problema esse que, por anos, também dificultou o trabalho do CNP.

Em 2 de abril de 1954, por meio do Decreto n 35.308, é aprovada a Constituição da Petróleo Brasileiro S.A., tendo na descrição do seu Art. 45ำ que "A sociedade contribuirá para a preparação de pessoal técnico e de operários qualificados, 
através de cursos de especialização, concessão de auxílios, bôlsas de estudos ou de outros meios adequados" (LEGISLAÇÃO BRASILEIRA..., s.d., p. 255).

A Petrobras iniciou suas atividades em 1954, recebendo o acervo do CNP e absorvendo-o gradativamente à sua estrutura. Com o CNP, os dados até 1952 indicavam um total de 311 poços perfurados desde o início de suas atividades; "Dêsse total, 180 produzem óleo, 24 gás e 107 são secos; 295 estão localizados no Estado da Bahia, 7 em Alagoas, 4 em Sergipe, 2 no Território do Acre, 2 no Pará e 1 no Maranhão" (VARGAS, G., 1964, p. 134). Ressalta-se que a quantidade de óleo produzida ainda era considerada relativamente baixa para elevar o Brasil ao nível de país autossuficiente na produção de petróleo.

A Petrobras investiu, então, na ampliação do acervo recebido. Parte dessa ampliação se destinou à exploração e à "preparação, a curto e a longo prazo, de pessoal especializado de vários escalões profissionais e só constituindo, dentro de si, um órgão com tais atribuições específicas, poderia a PETROBRÁS preencher a lacuna do sistema escolar vigente no país" (OLIVEIRA, C., 1961, p. 141).

Dentro dos "recursos financeiros e humanos da Nação", a ela confiados por lei, a PETROBRÁS não dispunha do imenso capital, know-how e tecnologia somados e centuplicados pelas grandes companhias de petróleo internacionais, no decurso de quase 100 anos, pelo mundo fora. Ampliou aceleradamente o seu parque industrial, para reduzir ao mínimo ou estancar a gravosa importação de derivados e financiar a Exploração; promoveu a especialização de dezenas de 
técnicos no exterior; aqui mesmo, no Centro de Aperfeiçoamento e Pesquisas de Petróleo (CENAP), [...] adestrou numeroso contingente de mão-de-obra, não formada no País pelos currículos de ensino. E, atirou-se a todas as nossas bacias sedimentares em busca do petróleo (MOURA; CARNEIRO, 1976, p. 307).

A ideia advinda desde o CNP era a de formar "equipes de técnicos brasileiros que atendessem às crescentes necessidades" e que "reduzissem ao máximo a contratação de profissionais estrangeiros substituindo-os gradativamente por técnicos nacionais" (FORTES, 2003, p. 3). Essa substituição, de fato, não ocorreu imediatamente, pois as crescentes demandas internas e a expansão da indústria do petróleo surgidas na Petrobras exigiam muitos profissionais e o desenvolvimento de um know-how próprio, o que somente se conseguiria com a contribuição de estrangeiros naquele momento. Pretendia-se, ainda, a substituição dos estrangeiros por brasileiros nos cargos mais altos da Petrobras, fazendo, com isso, cessar os gastos com pagamentos realizados, em sua maior parte, em dólares.

$\mathrm{Na}$ organização interna geral da Petrobras de 1955, coube ao plano de operações da empresa treze unidades atuantes em diferentes áreas (Conforme Figura 9, p. 116), sendo uma delas o Departamento de Exploração (DEPEX), unidade de análise neste livro por dois motivos: 1) o cargo máximo de Superintendente Chefe do DEPEX pertenceu primeiramente a um geólogo estrangeiro; e 2) o Departamento era responsável pela descoberta de poços de petróleo no país e pelo seu gerenciamento. Foi também em 1955 que a Petrobras criou um órgão próprio de aperfeiçoamento e de 
profissionalização, chamado CENAP, como aponta a citação referida de Moura e Carneiro. Tal órgão será objeto de estudo na terceira parte deste livro. Por ora, trataremos do DEPEX.

Em 1954, a Petrobras tomou uma atitude que, mais tarde, modificaria a história do petróleo no Brasil, bem como a de seus avanços. 0 destacado geólogo de petróleo Arville Irving Levorsen (1894-1965) entrou em contato com o geólogo norte-americano Walter Link (1902-1982) a fim de contratá-lo para o cargo máximo do Departamento de Exploração, tendo como desafio "organizar um Departamento de Exploração, calcado nos moldes das mais bem sucedidas companhias internacionais" e informar a Petrobras sobre "as possibilidades petrolíferas do Brasil" (LINK, 1961, p. 1).

Nesse período, Walter Karl Link era considerado por seus pares um dos seis melhores geólogos quando se tratava de exploração de petróleo (EUGÊNIO GUDIN..., 1954). Link formou-se em Geologia na University of Wisconsin-Madinson, nos Estados Unidos, e adquiriu uma vasta experiência ao trabalhar para a empresa Standard Oil Co. Louisiana, em Shreveport, e para a Standard Oil Co. de New Jersey (HUMPREY; SANFORD, 1983, p. 1040) realizando mapeamentos de depósitos petrolíferos em países da América Latina, como Venezuela, Colômbia e Equador, entre outros (DOTTO JR, 2001).

No final de junho e princípio de julho de 1954, Link realizou uma visita preliminar ao Brasil, tendo tido contato diretamente com o então presidente da Petrobras, o Coronel Juracy Montenegro Magalhães (1905-2001) ${ }^{97}$, e dois diretores

${ }_{97}$ Militar e político brasileiro. Foi o primeiro Presidente da Petrobras (de 02 de abril de 1954 até 02 de setembro de 1954). 
da Companhia - Irnack Carvalho do Amaral (1905-1983) ${ }^{98} \mathrm{e}$ João Neiva de Figueiredo ${ }^{99}$. Os jornais locais reagiram de diferentes formas à contratação de Link: por um lado, apoiaram a presença de um especialista reconhecido para encontrar petróleo no Brasil; porém, por outro lado, o fato de o geólogo ser um antigo funcionário da Standard Oil contribuiu para que os nacionalistas o considerassem um homem com interesses internacionais e não nacionais. Apesar do conflito de ideias exposto nos meios de comunicação, pela primeira vez um estrangeiro assumiria um cargo de tal importância no Brasil, o de Superintendente-Chefe ${ }^{100}$ do Departamento de Exploração da Petrobras, tendo como responsabilidade encontrar petróleo e buscar a autossuficiência tão almejada.

\footnotetext{
${ }^{98}$ Engenheiro de minas e civis. Foi o décimo Presidente da Petrobras (de 30 de junho de 1966 até 27 de março de 1967).

${ }^{99}$ Engenheiro de minas e civis.

100 Para compreender a importância que aqui damos ao cargo de Superintendente-Chefe de uma empresa, é importante analisarmos a estrutura social brasileira dos fins da década de 1950. Por exemplo, na classificação profissional dos moradores da cidade de São Paulo, tem-se, no topo da sociedade, as posições de diretor superintendente, fazendeiro, gerente, advogado, médico, padre e jornalista, situação decorrente dos avanços dos processos de secularização e de mercantilização da sociedade brasileira na época. MELLO, João Manuel Cardoso de; NOVAIS, Fernando Antonio. Capitalismo tardio e sociabilidade moderna. (SCHWARCZ, 1998).
} 


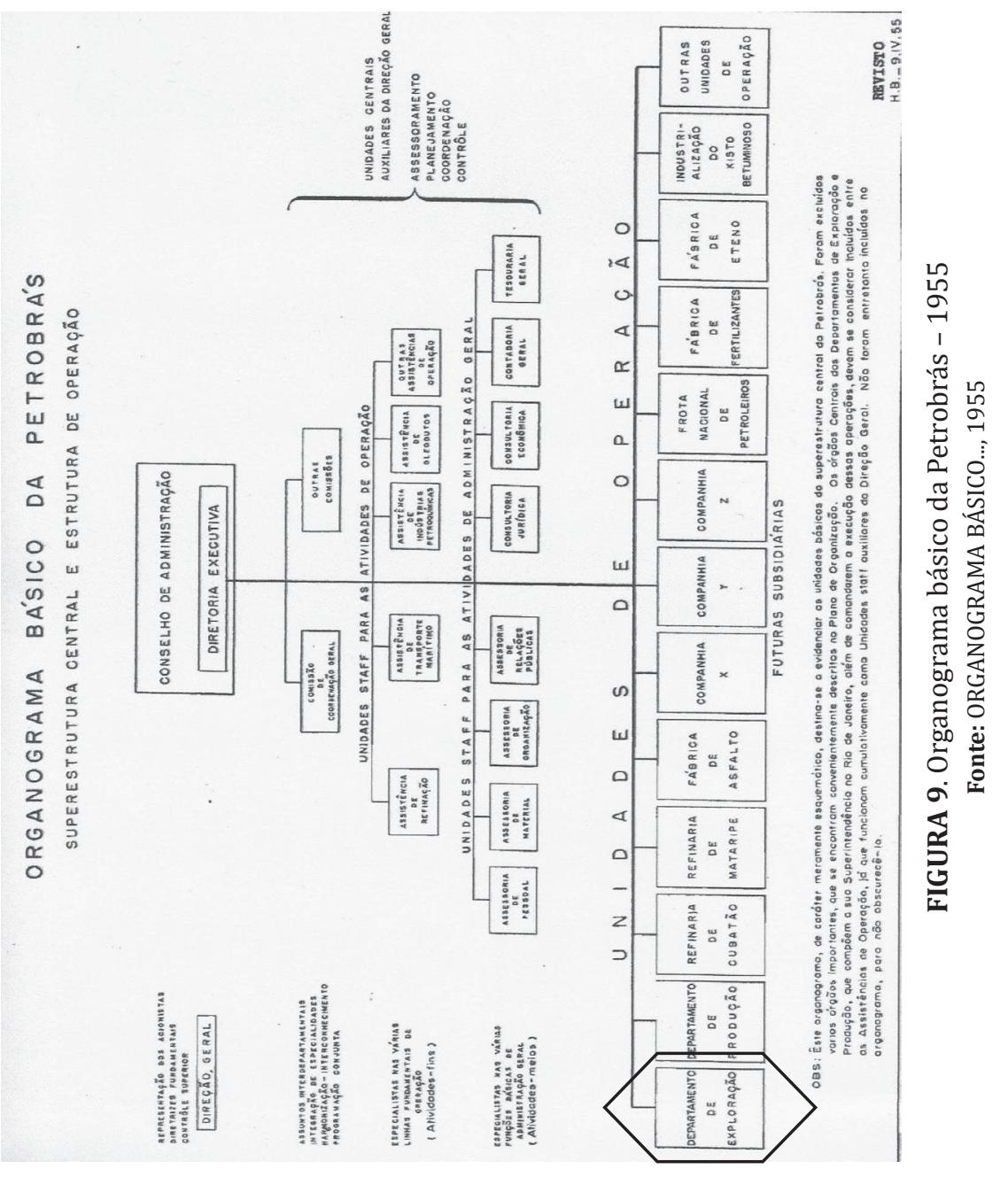


Assim, a contratação de Link estava relacionada também ao desejo da Petrobras em organizar o DEPEX "calcado nos moldes das mais bem sucedidas companhias internacionais, e [ao fato de] que a Companhia desejava saber quais as possibilidades petrolíferas do Brasil" (LINK, 1961, p. 1), até então desconhecidas devido à extensão do território e ao conhecimento geológico que se tinha dessas áreas. Nesse momento, a Petrobras priorizava a exploração, pois era preciso encontrar petróleo para justificar todos os investimentos, bem como a sua própria criação. Em outubro de 1954, quando Link inicia seu trabalho na Petrobras, ele descreveu a situação que encontrou:

Na ocasião da minha chegada ao Brasil, não existia nenhum grupo exploratório pertencente à PETROBRAS no escritório do Rio. O CNP ainda controlava a exploração através da firma consultora DeGolyer \& MacNaughton, sob contrato com o C.N.P. Havia em atividade no campo três turmas geológicas de superfície no sul do Brasil, uma no Maranhão e duas no Recôncavo. Existiam uma equipe sísmica no Recôncavo, duas no Maranhão e duas no Amazonas. Um poço pioneiro estava parado esperando por material em Jacarezinho no estado do Paraná, e dois em perfuração no Amazonas. Havia uma equipe de gravimetria no Recôncavo, que estava virtualmente parada ha 18 meses devido à falta de transporte, e uma no Tapajós no Amazonas. [...] As condições dessas áreas eram caóticas. 0 pessoal, especialmente os estrangeiros, não eram pagos ha meses, assim como as companhias de perfuração contratadas. A maioria das equipes estava parada por falta de material, transporte, fundos, gasolina, dinamite e outros ítens essenciais (LINK, 1961, p. 2).

Destaca-se que a firma consultora DeGolyer \& MacNaughton era reconhecida pelos seus trabalhos com a 
geofísica e tinha como um dos principais intuitos aplicar os recentes avanços tecnológicos dessa área para encontrar petróleo no Brasil. A princípio, ela atuou como prestadora de serviços de 1944 até 1954, no Brasil, em contrato realizado com o CNP.

As condições então encontradas por Link não eram nem um pouco favoráveis. Era preciso organizar o trabalho realizado pelo CNP, agora Petrobras, reintroduzir uma nova metodologia, oferecer melhores condições de trabalho e introduzir novas tecnologias.

Paralelamente ao trabalho de Link, iniciava-se a organização do DEPEX, ainda em 1954, pelo economista e administrador Hélio Marcos Pena Beltrão (1916-1997) ${ }^{101}$. 0 plano foi considerado por Link como simples, mas conciso, e, por isso, foi mantido.

No início do funcionamento do DEPEX, suas atividades eram divididas e executadas por distritos regionais, implantados em bacias de potencial petrolífero e diretamente subordinados ao Superintendente Chefe desse Departamento, Walter Link. Os Laboratórios de Paleontologia e Estratigrafia foram incorporados a esses Distritos (MEMÓRIAS DA..., 2003).

Abre-se um parêntese para destacar a importância do investimento da Petrobras e, principalmente, do DEPEX em Laboratórios de Paleontologia ${ }^{102}$, Estratigrafia e, logo em

${ }^{101}$ Formou-se em Direito na Faculdade Nacional de Direito. Foi Ministro do Planejamento na ditadura militar. Ocupou o cargo de presidente da Petrobras de 19 de março de 1985 até 15 de maio de 1986.

102 Por muito tempo as "pesquisas na área de Geologia e Paleontologia eram restritas às observações de campo e de amostras pontuais de sedimentos na busca por ocasionais achados fossilíferos. Com a rápida expansão das pesquisas exploratórias e o crescente volume de amostras provenientes de poços perfurados, houve uma exigência por estudos precisos 
seguida, de Sedimentologia. Grandes avanços científicos e de formação do know-how relacionaram-se especificamente à Micropaleontologia e à Palinologia exercidas nesse período pelos profissionais da empresa e prosseguiram em expansão, contribuindo significativamente para novas descobertas petrolíferas.

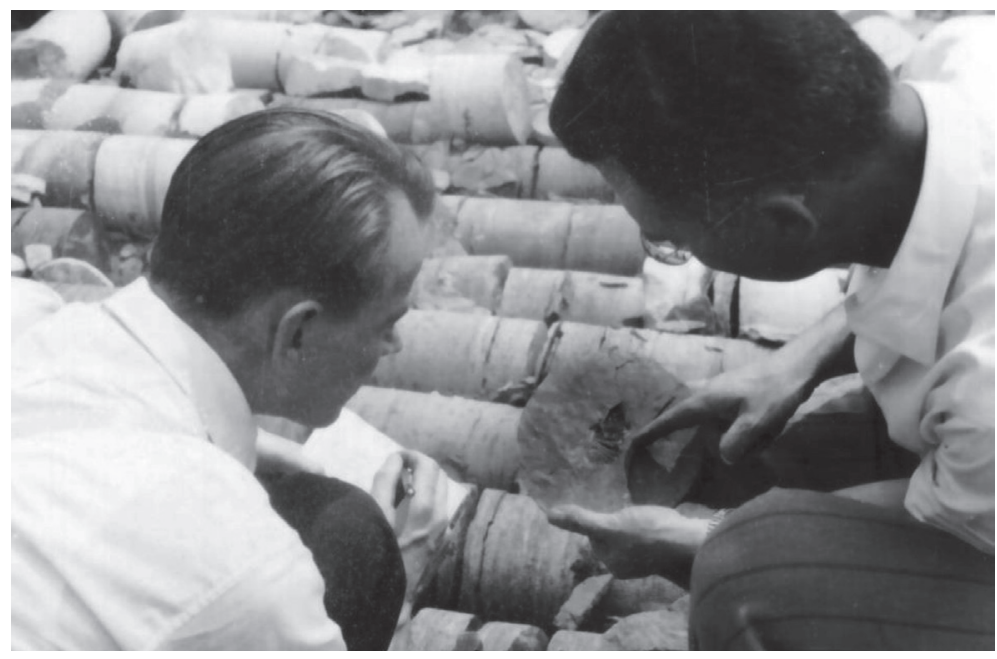

FIGURA 10. 0 paleontólogo Frederico Waldemar Lange (à direita) em trabalho de campo pela Petrobras (meados da década de 50)

Fonte: FREDERICO WALDEMAR..., s.d.

Para José Luciano de Mattos Dias e Maria Ana Quaglino, Walter Link teve como características instituir um programa

do material sedimentar fragmentado, visando descrever as características litológicas e outros elementos característicos. Os microfósseis encontrados nos sedimentos perfurados mostraram ser importantes como indicadores do ambiente de deposição dos sedimentos e para sua datação, reduzindo os custos e otimizando a exploração do petróleo. A partir desse reconhecimento, a Micropaleontologia revelou-se uma ferramenta importante na prospecção do petróleo" (MEMÓRIAS DA..., 2003, p. 8). 
de exploração bastante ambicioso (DIAS; QUAGLINO, 1993), mas que foi essencial para mudar os rumos de exploração no Brasil. 0 geólogo americano complementou o Departamento de Exploração com uma estrutura organizacional nos moldes da indústria americana e recolheu estudos e pesquisas anteriores das bacias sedimentares brasileiras, bem como visitou parte destas para reconhecimento geológico das áreas, decidindo centrar suas atividades em dois pontos: a) no desenvolvimento da exploração na Bahia; e b) sondar as maiores bacias sedimentares brasileiras (Bacia do Amazonas, pela sua vastidão, e a Bacia do Paraná, pela relevância geográfica e econômica). Ambos os pontos indicavam uma "quase certeza de encontrar novos campos petrolíferos" (MOURA; CARNEIRO, 1976, p. 308). Link investiu ainda na contratação de geólogos e de geofísicos estrangeiros, além de conseguir estágio aos brasileiros em diferentes universidades no exterior, em comum acordo com o CENAP.

Para uma maior elucidação dos estudos recolhidos por Walter Link e dos mapas elaborados no período, os quais demonstravam as bacias com maior chance de se encontrar petróleo, trazemos o mapa sobre a classificação das condições petrolíferas do Brasil, elaborado em 1948 e apresentado por Juarez Távora no livro Petróleo para o Brasil, de 1955. Ele pode ser comparado com os outros mapas presentes ainda nesta parte deste livro. Na tentativa de confirmar essas possibilidades, montaram-se equipes de campo dentro do DEPEX e de seus respectivos distritos para o estudo e pesquisa dessas bacias.

Reitera-se que, desde o início, tanto pelo CNP quanto pela Petrobras, o objetivo era alcançar a autossuficiência na produção de petróleo. Isso se tornou um desafio na medida em 
que não se encontravam poços comercialmente exploráveis e o país se industrializava, aumentando a sua necessidade.

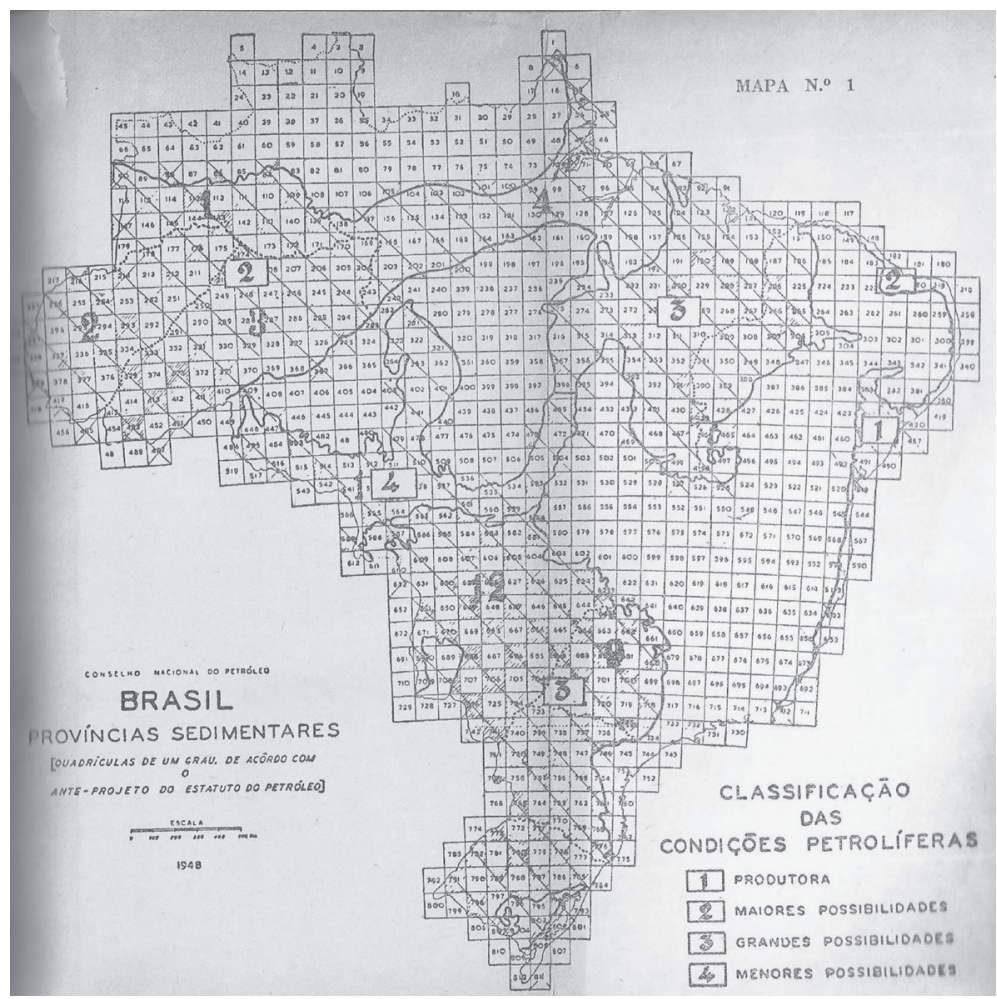

FIGURA 11. Bacias sedimentares brasileiras (1948)

Fonte: TÁVORA, 1955

Em 1958, Link insistia que um dos pontos fracos da Petrobras, no que concerne às tentativas de resolução do problema de encontrar petróleo no país, continuava a ser o treinamento de brasileiros para a formação da técnica nacional, isso acrescido à dificuldade que ela tinha de recrutar pessoal qualificado devido a sua escassez (PASSARINHO, 1958). 
Essas afirmações estão calcadas no relato de Link de que, no começo das atividades do DEPEX, foi realizado o treinamento de 50 brasileiros, sendo que, ao fim deste, a maioria dos profissionais abandonou a carreira com a justificativa de que o trabalho e as atividades realizadas na área de geologia e de geofísica eram demasiadamente pesadas para eles, de que enfrentavam problemas familiares e de que os salários era baixos. Em contrapartida, Link enfatizava que os esforços do CENAP vinham contribuindo para mudanças positivas desse cenário (LINK, 1961, p. 2).

Mesmo diante de tais dificuldades, inúmeras pesquisas foram realizadas por Link e por sua equipe. Em 1959, durante $05^{\circ}$ Congresso Mundial de Petróleo, ele apresentou os primeiros resultados, pessimistas, quanto a encontrar petróleo no território brasileiro (SMITH, 1978).

Em face dessas declarações de Link, a Petrobras começa, já em 1959, a tomar atitudes para modificar o quadro crítico que aparentemente se inicia no país nos campos político, econômico e social. Investe-se, assim, no intercâmbio técnico-científico e na contratação de profissionais, buscando um novo parecer das bacias sedimentares brasileiras ou ainda de novas técnicas para se encontrar petróleo no território. Como exemplo, cita-se a chegada ao Brasil do geólogo Claude de Lapparent (1920-1985) ${ }^{103}$, diretor do Serviço de Geologia da Cia. Francesa de Petróleo (Argélia), que visitou os trabalhos desenvolvidos pela Petrobras, principalmente no Recôncavo Baiano e em alguns órgãos técnicos, bem como proferiu conferências, inclusive na Escola Técnica do exército brasileiro

103 Diplomado pela Sorbonne em Ciências e pelo Instituto Francês de Petróleo em Geologia. Filho e neto de geólogos. Vale citar que o Tratado de Mineralogia de autoria de seu avô é obra clássica na área de geologia. 
e no Clube de Engenharia, ambas no Rio de Janeiro e relacionadas às explorações no Saara (FAMOSO GEÓLOGO..., 1959).

Posteriormente, algumas empresas estrangeiras, como as mencionadas, que participaram desse intercâmbio científico mostraram insatisfação pela falta de continuação dos trabalhos no Brasil, pois sua participação ficou cada vez mais limitada. A Petrobras buscava mais uma breve visita a áreas pouco desconhecidas, com maior ênfase no estudo dos trabalhos já existentes do que nas investigações a serem realizadas pelas empresas estrangeiras. Ou seja, essa vinda de estrangeiros ao país restringira mais a orientação e consulta do que a execução própria dos serviços exploratórios de outros países. A Petrobras procurava formar sua própria técnica à base de informações estrangeiras. Logo, as empresas estrangeiras demonstravam descontentamento perante as atitudes da empresa (LANGE, 1961).

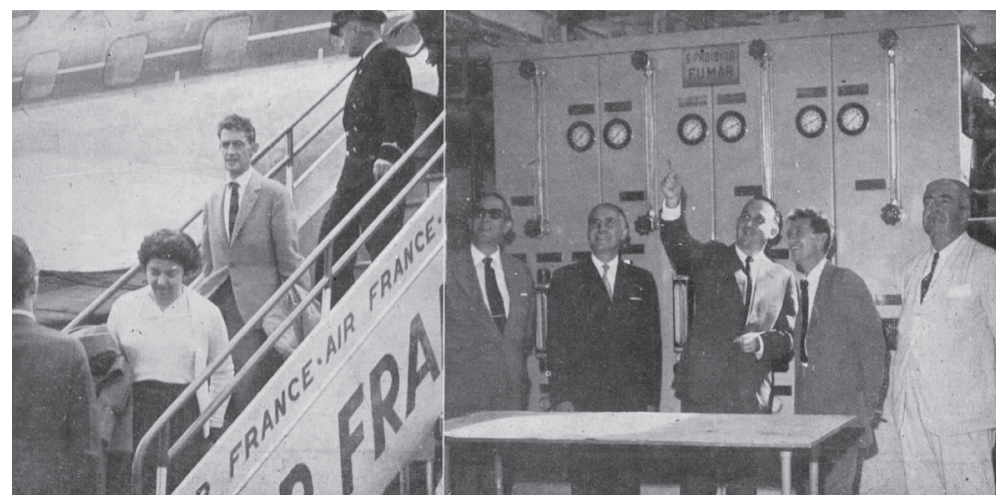

FIGURA 12. "Famoso geólogo francês visita o Brasil" dezembro de 1959. À esquerda, o geólogo Lapparent quando descia do avião que o trouxe ao Rio; à direita, em visita ao CENAP, ele ouve explicações do professor F. Campbell Williams Fonte: FAMOSO GEÓLOGO..., 1959, p. 5. 
Foi em 1960, com base nos resultados das pesquisas realizadas por Link na Bacia do Amazonas, que a situação ficou crítica. A Bacia do Amazonas foi a principal aposta da Petrobras e de Link desde o início das atividades para se encontrar novos poços petrolíferos, e os investimentos nela somavam $60 \%$ de toda a dotação orçamentária de exploração (LINK, 1960). O local também já havia sido indicado, como mencionado na primeira parte deste livro, pelo geólogo Israel Charles White, que concluiu, no Relatório White (1908), “que as intrusões de rochas eruptivas nas formações sedimentares tornam improvavel a existencia de grandes lençóes de petroleo, a não ser nos terrenos devonianos da bacia amazônica" (PEDREIRA, 1927, p. 14, grifo nosso). A Bacia do Amazonas, no mapa representado anteriormente (Figura 11), novamente era considerada como de maiores possibilidades de se encontrar petróleo.

No mesmo ano, compilando todos os dados obtidos nas pesquisas desenvolvidas na Bacia do Amazonas desde 1955, e considerando os fatores geológicos tal como interpretados no período, Walter Link concluiu que, após anos de trabalho de equipes de sísmicas, de gravimetria, de geologia de campo, de perfurações, e também de:

[..] fotografia aérea; e pesquisas de aeromagnetometria em $60.000 \mathrm{~km}^{2}$ na área de Nova Olinda; a perfuração de 100 poços secos, e finalmente um investimento de quase 200 milhões de dólares, é impossível para mim chegar a outra conclusão de que a exploração em larga escala deverá ou ser suspensa ou reduzida drasticamente a uma base experimental. Talvez daqui a dez anos novas técnicas geofísicas poderão ter surgido que possam resolver o problema geofísico. A geologia, porém, não mudará e eu não creio que a 
bacia amazônica possua os requisitos geológicos necessários para tornar-se uma grande região produtora de petróleo (LINK, 1961, p. 2).

Nessa senda, Link realizou uma estimativa para encontrar petróleo nas bacias sedimentares brasileiras de um poço com possibilidade de produção para cada 275 perfurados, acrescentando que eram investidos técnica e conhecimento geológico e geofísico existentes no momento (LINK, 1961). Por fim, o geólogo recomendou que a Petrobras deveria investir em outras áreas para exploração, mas quais seriam elas?

Em agosto de 1960, Link apresentou ao presidente da empresa, General Idálio Sardenberg, "um detalhado relatório dos seis anos de pesquisa no Brasil [...] [que] exprimia as opiniões de quatorze destacados geólogos (seis brasileiros e oito estrangeiros)" (SMITH, 1978, p. 137) pertencentes ao DEPEX. As informações descritas no relatório não eram animadoras. Link ressaltava que as pesquisas deveriam ser direcionadas para a plataforma continental, pois ali estaria a nova fonte de petróleo e gás natural do Brasil, ou para o investimento em outros países.

0 Relatório Link, ${ }^{104}$ considerado confidencial, vazou na imprensa e teve repercussão nacional e internacional. "O relatório caiu como uma bomba na opinião pública, pois questionava a existência de grandes depósitos de petróleo no Brasil, uma das crenças dos setores nacionalistas" (COSTA, s.d.).

O relatório "confidencial" apareceu em vários jornais do Rio de Janeiro em meados de novembro de 1960,

104 De acordo com Azevedo e Terra (2008, p. 381), o relatório é composto por três cartas e "no jargão popular, ficou conhecido como o 'Relatório Link"'. A elas segue um quarto documento contendo a proposta de orçamento exploratório para o ano de 1961. 
e Gabriel Passos ${ }^{105}$ divulgou seu teor na Câmara dos Deputados, acusando Link de ter "sabotado" o esforço exploratório da Petrobrás porque secretamente ainda estava a serviço da Standard Oil de New Jersey. Passos alegou que Link sempre ordenava que "se interrompesse a perfuração assim que eram observados os indícios de petróleo". Chegou a afirmar que Link fora contratado por engano e que a Petrobrás apressou-se em esclarecer a situação de Link na companhia e terminou dizendo: "A opinião da Petrobrás é a de que o óleo no Brasil é economicamente aproveitável" (SMITH, 1978, p. 137-138).

Muitas informações, como as acima descritas, tornaram-se mais tentativas de apaziguar as notícias negativas a respeito do petróleo do território brasileiro e encontrar um culpado - nesse caso, Walter Link - do que de levar em conta todos os dados e investir em novas soluções perante o problema. Ainda nesse caso, a discussão não se restringe somente à Petrobras e aos problemas de gestão interna da empresa, principalmente no referente à opinião de pessoas públicas, mas se torna uma questão nacional. Como disse Walter Link, "discursos políticos, artigos ou livros de escritores, ataques aos homens que procuram desvendar a geologia e os problemas da sua terra, em nada poderão modificar as condições geológicas existentes e nem colocar petróleo no subsolo" (WALTER LINK..., 1961, p. 17). Um caso de crítica pública em específico é a do Deputado Ferro Costa, que vai além das considerações do referido Relatório, não acusando Link, mas focando nas irregularidades internas da Petrobras:

105 Gabriel de Resende Passos (1901-1962) nasceu em Itapecerica (MG). Em 1924, bacharelou-se em Ciências jurídicas e sociais pela Faculdade de Direito de Belo Horizonte. Atuou como advogado, jornalista e político, sendo eleito deputado federal. Também atuou como Procurador-geral da República (1936) e Ministro das Minas e Energia (1961). 
Não estará o Sr. Link, a esta altura dos acontecimentos, sendo usado como bode expiatório? A campanha contra o Sr. Link não será uma cortina de fumaça para encobrir irregularidades em outro setores da PETROBRAS [...] Por que a PETROBRAS não elaborou até agora, um plano nacional de refino? E a questão da produção de lubrificantes básicos pela Refinaria de Mataripe? E a situação financeira da Frota Nacional de Petroleiros? A orientação da PETROBRAS, no que se refere não só as pesquisas, como, ainda, à localização de refinarias e oleodutos, não estará obedecendo mais a critérios de natureza política ou regional do que puramente econômico? Há, mesmo, uma política nacional do petróleo? (A CONFUSÃO..., 1960).

Link foi chamado pela imprensa e por outros meio de comunicação de "inimigo público $n^{0}$ 1", "sabotador $n^{\circ} 1$ ", "instrumento da Standard Oil Company" e "entreguista ${ }^{\circ} 1$ ". 0 geólogo norte-americano também foi duramente criticado principalmente em "jornais como o Semanário, Última Hora, Novos Rumos, e em um jornal de Maceió, Alagoas. Ataques mais moderados ocorreram no Paraná e em São Luiz, Maranhão" (LINK, 1961, p. 2). Em sua defesa, ele classificou tais atitudes como contínuos ataques pessoais. A revista $O$ Cruzeiro definiu bem a situação de Link: "Combatido por uns, aplaudido por outros, o geólogo norte-americano deixou o Brasil ao terminar seu contrato com a PETROBRÁS" (WALTER LINK..., 1961, p. 17), em dezembro de $1960 .{ }^{106}$ Em 1961, antes de voltar aos Estados Unidos, Walter Link descreveu que:

O meu único sentimento é o fato de não ter sido possível encontrar petróleo nas extensas regiões fora da bacia do Recôncavo. Com a possível exceção da

106 Alguns meses antes, a Petrobras tentou renovar o contrato de Link por mais dois anos, mas ele optou por encerrar seu prazo na empresa devido aos resultados descritos e aos crescentes ataques pessoais. 
bacia de Tucano, presentemente em fase de exploração, as outras bacias sedimentares permanecem com possibilidades pouco encorajadoras. Não direi que nenhum óleo será nelas encontrado, mas duvido que se venham a encontrar campos grandes capazes de um desenvolvimento econômico e em escala comercial (WALTER LINK..., 1961, p. 17).

Em resumo, o começo da década de 1960 foi turbulento para a Petrobras e para o Brasil. Além de as palavras de Walter Link atormentarem a política e a economia do petróleo, havia a pressão exercida pela sociedade. Parecia inacreditável que um país com tal extensão territorial não possuísse petróleo comercializável. Para agravar a situação, os dados de exploração de petróleo do Brasil, comparado a outros países de extensões territoriais menores, eram desanimadores. Afirmações do presidente Juscelino Kubitschek, alguns meses antes da publicação do Relatório Link, afirmando que o Brasil ultrapassara a meta de produção de petróleo, colocaram em descrédito o plano de governo nesse aspecto (ATINGIDAS E..., 1960).

A representação viria por meio de dados e de mapa:

TABELA 1. Produção mundial de petróleo bruto - 1955/1960

\begin{tabular}{lcccccc}
\hline Países & \multicolumn{6}{c}{ Produção Média Diárias (milhares de barris) } \\
\hline & $\mathbf{1 9 5 5}$ & $\mathbf{1 9 5 6}$ & $\mathbf{1 9 5 7}$ & $\mathbf{1 9 5 8}$ & $\mathbf{1 9 5 9}$ & $\mathbf{1 9 6 0}$ \\
\hline Estados Unidos & 6.807 & 7.151 & 7.170 & 6.709 & 7.042 & 7.077 \\
México & 250 & 257 & 253 & 276 & 290 & 264 \\
Venezuela & 2.157 & 2.457 & 2.779 & 2.606 & 2.768 & 2.905 \\
Brasil & 6 & 11 & 28 & 52 & 65 & 71 \\
Holanda & 20 & 21 & 29 & 31 & 34 & 35 \\
França & 17 & 25 & 28 & 28 & 31 & 39 \\
Alemanha & 61 & 68 & 77 & 86 & 99 & 108 \\
\hline
\end{tabular}

Fonte: PRODUÇÃO MUNDIAL..., 1961, p. 1 


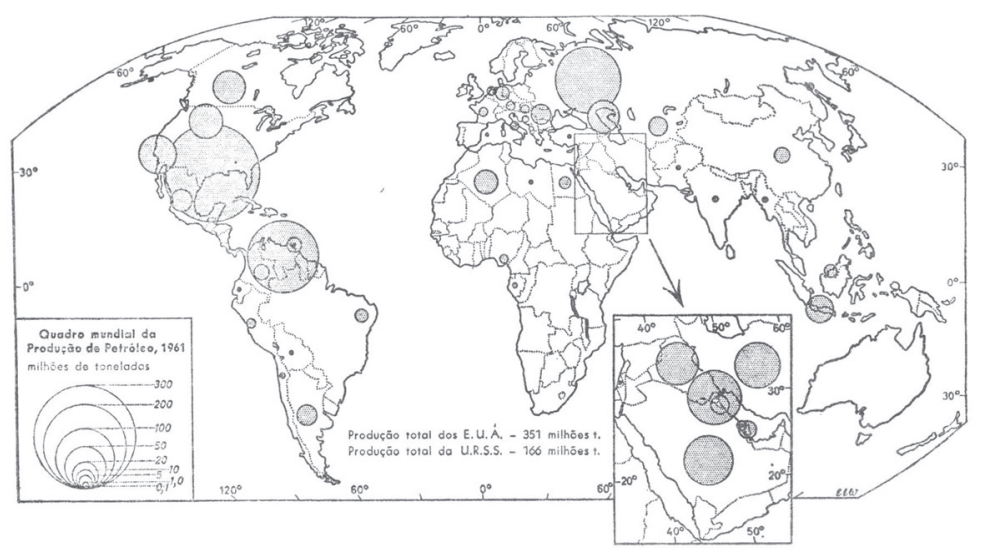

FIGURA 13. Quadro mundial da produção de petróleo - 1961

Fonte: ODELL, 1966

Em decorrência da repercussão do Relatório Link, e considerando-se os contatos que a Petrobras estabeleceu com outras indústrias internacionais no intuito apenas de reverter o quadro negativo pós-relatório, em dezembro de 1960 foram contratados técnicos franceses para "um novo levantamento geológico das regiões do país onde se admite a existência do petróleo, já que não dispõe de elementos para contestar o Relatório Link e não pretende aceitar as conclusões dêsse relatório como definitivas" (PETROBRAS VAI..., 1961, p. 3). Em março de 1961, direcionados pela Petrobras, os geólogos Pedro de Moura e Décio Savério Oddone reavaliam o Relatório Link (DIAS; QUAGLINO, 1993, p. 119) que estabelecia a classificação das bacias em:

Classificava como "A" as bacias que contavam com produção comercial, em que os esforços exploratórios deviam continuar. Eram as bacias em que todas as condições mencionadas estavam presentes. 
Como "B" as bacias que apresentavam existência de rochas matrizes, mas onde podiam não estar presentes rochas porosas ou fraturadas ou sem ocorrência de estruturas ou outras condições geológicas favoráveis. Nelas os fatores geológicos indicavam que havia possibilidades de descoberta comerciais. Eram áreas em que a exploração deveria ser continuada.

Como " $\mathrm{C}$ " as bacias marginais, que teriam fracas ou limitadas características de rochas matrizes e pouca evidência da existência de reservatórios ou estruturas, nas quais havia feito um grande esforço exploratório, sem resultados. Nestas regiões, poderia ser realizada, ainda, alguma exploração.

Como "D" as bacias em que não havia possibilidade de existência de petróleo, por não apresentarem a existência de rochas matrizes. Nestas bacias, não se deveria realizar mais trabalhos de exploração (COSTA, s.d., p. 19).

Algumas letras foram acompanhadas de símbolo de “+” ou "-" de acordo com os resultados diagnosticados, não influindo isso muito nos resultados finais. Assim, os geólogos chegaram à seguinte conclusão em relação ao Relatório Link:

TABELA 2. Avaliação das possibilidades petrolíferas no Brasil

\begin{tabular}{lcc}
\hline Bacias & Link (1960) & Moura - Oddone (1961) \\
\hline Baixo Amazonas & D & D \\
Médio Amazonas & $\mathrm{C}$ & $\mathrm{C}+$ \\
Alto Amazonas & $\mathrm{D}$ & $\mathrm{D}$ \\
Acre & $\mathrm{D}+$ & $\mathrm{C}-$ \\
São Luís / Maranhão & $\mathrm{D}+$ & $\mathrm{D}$ \\
Barreirinhas & $\mathrm{D}$ & $\mathrm{B}$ \\
Maranhão (Sudoeste PI/MA) & $\mathrm{D}-$ & $\mathrm{C}$ \\
Sergipe terrestre & $\mathrm{C}-$ & $\mathrm{B}$ \\
Alagoas terrestre & $\mathrm{C}-$ & $\mathrm{B}$ \\
Espírito Santo/Sul Bahia & $\mathrm{D}$ & $\mathrm{D}$ \\
Sul Brasil & $\mathrm{D}$ & $\mathrm{C}-$ \\
Recôncavo & $\mathrm{A}$ & $\mathrm{A}$ \\
\hline
\end{tabular}

Fonte: MOURA; CARNEIRO, 1976, p. 331 
Por meio dessa tabela, é possível verificar que os dados pouco diferem, com exceção específica de algumas bacias. Assim, a Petrobras, relutou em aceitar as palavras de Link, negando-se a investir precisamente em pesquisas na plataforma continental e insistindo na exploração do território mesmo com a apresentação dos dados acima. Somente anos mais tarde a Petrobras reconheceu que Walter Link estava com razão.

Em 1ํ de janeiro de 1961, por indicação de Link nomeou-se o paleontólogo Frederico Waldemar Lange para o cargo de Superintendente Chefe do Departamento de Exploração do DEPEX (anteriormente ocupado por Link), o que gerou uma nova revolta na imprensa.

A substituição de Link por Lange foi muito criticada e intitulada, em meio aos jornais, uma "escolha infeliz" (CONTESTAM OS..., 1960, p. 6), afirmando-se que seria um brasileiro ensinado por um estrangeiro a ocupar o cargo de Superintendente do DEPEX (PEYERL, 2010).

[...] a escolha do Dr. Lange é absolutamente infeliz, porquanto, dentre os técnicos da Petrobrás, no momento, nenhum está mais próximo das concepções e da orientação do Sr. Link do que o Dr. Lange, se é que há alguma diferença de pontos-de-vista entre os dois. Tal afinidade é tão pronunciada que se evidencia da simples leitura de documentos internos da Petrobrás, onde existem técnicos estrangeiros menos pessimistas (CONTESTAM OS..., 1960, p. 6).

Lange já tinha conhecimento das deficiências da Petrobras, tanto que, em 31 março de 1959, Link lhe enviou uma carta enfatizando a necessidade de ter bons técnicos 
estrangeiros durante os próximos anos, com a esperança de que, durante esse tempo, os "melhores brasileiros" se desenvolvessem o suficiente para assumir os postos de trabalho dentro da Petrobras (LINK, 1959). Essa proposta de Link foi implantada pela Petrobras por meio do DEPEX, tomada de decisão que não ficou isenta de críticas.

No período em que Lange permaneceu como Superintendente Chefe do DEPEX, ele "realiza funções administrativas, propondo instalações de outros laboratórios nos Distritos, e também estudos mais profundos principalmente na região do Amazonas" (PEYERL, 2010, p. 75), estes parcialmente por insistência da Petrobras. 0 contato com outros países contribui para visitas técnicas e para estágios de profissionais no exterior, em locais como Institut Français des Pétroles, Compagnie Génerale de Geophysique, Agip Mineraria /ENI (Itália), Amt fuer Bodenforsschung, Compagnie Française des Pétroles, entre outros.

A partir do Acervo Frederico Waldemar Lange, que possui inúmeras informações sobre o período em que este ocupou o cargo máximo da exploração do petróleo, em 1961, foi possível compreender a participação de estrangeiros e a contínua construção de um know-how brasileiro. Por meio de levantamento realizado nas cartas e relatórios de tal acervo, principalmente no que tange ao início da década de 1960, os principais locais de estágio e visitas de brasileiros concentravam-se nos seguintes países: 


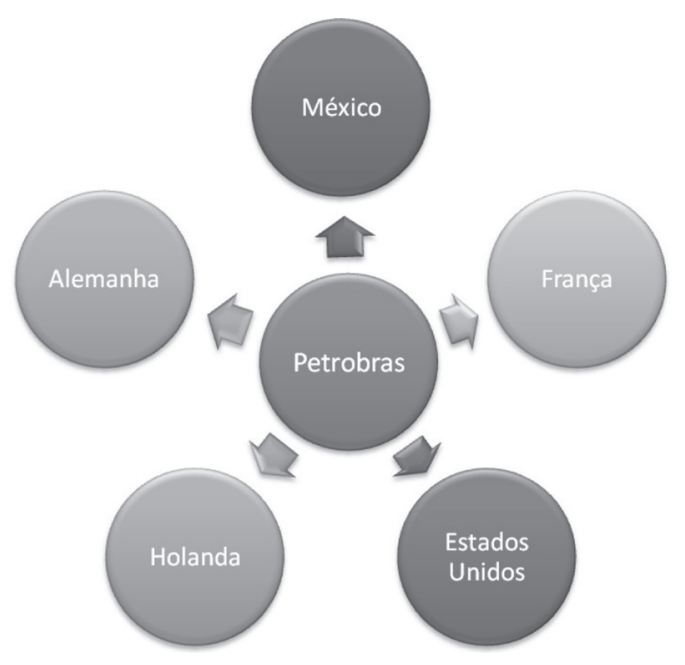

ORGANOGRAMA 2. Principais países de visita e de estágios de brasileiros (1958-1965)

Fonte: elaborado pela autora

A Petrobras, então, por meio do DEPEX, estreitou relações com esses países e com outros em busca de novas tecnologias e de aprimoramento do seu próprio know-how. Acresce-se a isso a relação que a França estabeleceu com o Brasil, principalmente na contribuição da estrutura de ensino na área de Petróleo, principalmente para o desenvolvimento do CENAP e de estágios no exterior.

Em agosto de 1961, parte dos integrantes do DEPEX e outros profissionais da Petrobras visitaram a Ente Nazionale Idrocarburi (ENI) ${ }^{107}$ na Itália. 0 motivo da viagem estava ligado à análise de aspectos gerais de exploração geológica e geofísica, perfuração marinha e eventual associação para a

107 A empresa foi fundada em 1953 pelo governo italiano com o objetivo de promover e desenvolver uma estratégia energética nacional. 
exploração conjunta de petróleo no exterior (LANGE, 1961). Era nesse ritmo de visitas e pesquisas que a Petrobras fortalecia o seu trabalho e buscava a construção do seu know-how.

Em 1961, a indústria brasileira do petróleo ainda não contava com um método capaz de antecipar quais as possibilidades de se revelar poços subcomerciais ou produtos de petróleo (AMARAL, 1961), Por isso, era necessário buscar tecnologia no exterior e adaptá-la às características geológicas do país.

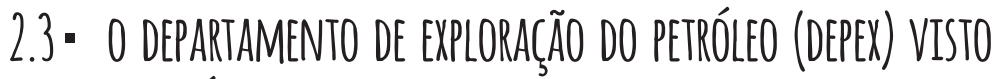 POR NÚMEROS}

Em 1959, é publicada a obra Aspectos Econômicos da Exploração do Petróleo no Brasil, de autoria de Frederico Waldemar Lange. 0 convite para a formulação da obra partiu do economista Hélio Beltrão (1916-1997), o qual teve uma grande participação, como já mencionado, na organização do DEPEX.

O fato de o petróleo não contribuir nem com $50 \%$ da energia produzida no país foi um dos motivos para a Petrobras investir parte de seu orçamento na sua exploração, "Isto é, na pesquisa para a descoberta do petróleo e no desenvolvimento das suas reservas, procurando por todos os meios desincumbir-se com sucesso da missão para a qual foi especialmente criada" (LANGE, 1961, p. 12). Desde o início, o objetivo fundamental do DEPEX foi a procura e o descobrimento de acumulações de óleo e gás em quantidade comercial. A organização do DEPEX era composta de duas estruturas: central e 
regional. A primeira (Superintendente Geral e equipe) oferecia suporte para a segunda (Distritos regionais divididos por bacias sedimentares).

Os distritos regionais eram divididos pela Bacia do Amazonas, Bacia do Maranhão, Bacia do Nordeste (abrangendo Sergipe e Alagoas), Bacia do Recôncavo, Bacia do Espírito Santo e Bacia Sedimentar do Paraná. Em 1961, o DEPEX operava na Bacia do Paraná com 72 sondas, na Bacia do Recôncavo, com 228 sondas, na Bacia de Sergipe/Alagoas, com 60 sondas, na Bacia do Amazonas, com 97 sondas, e na Bacia do Pará-Maranhão, com 23 sondas e com 6 perfurações marinhas (OLIVEIRA, 1961). Cabe lembrar que as técnicas utilizadas para perfurações marinhas ainda estavam em pleno desenvolvimento, e que o Brasil posteriormente foi inovador, construindo novas tecnologias para a exploração na plataforma continental. Por esse motivo, e pelas análises de documentos do Acervo Frederico Waldemar Lange, restringimo-nos aqui ao estudo das Bacias Sedimentares do Amazonas e do Maranhão, que correspondiam ao mesmo Distrito, do Nordeste (Sergipe e Alagoas), do Recôncavo e do Paraná, pois, no momento estudado, os investimentos/pesquisas eram maiores nessas bacias.

O estudo de cada bacia sedimentar apresentava peculiaridades diferentes e problemas especiais de exploração. Por exemplo, a Bacia do Amazonas era de difícil penetração, o transporte era realizado por meio de cursos de água e havia problemas geológicos de rochas intrusivas e de derrames basálticos, sendo que a espessura destes pode atingir muitas centenas de metros (LANGE, 1961). Em 1958, Walter Link assinalou que: "o problema do diabásio no Amazonas e sul do Brasil desafia as tentativas de trabalhar as estruturas com a 
sismografia; pràtícamente todos os equipamentos e técnicas imagináveis foram usados na solução deste problema [...]" (LANGE, 1961, p. 18).

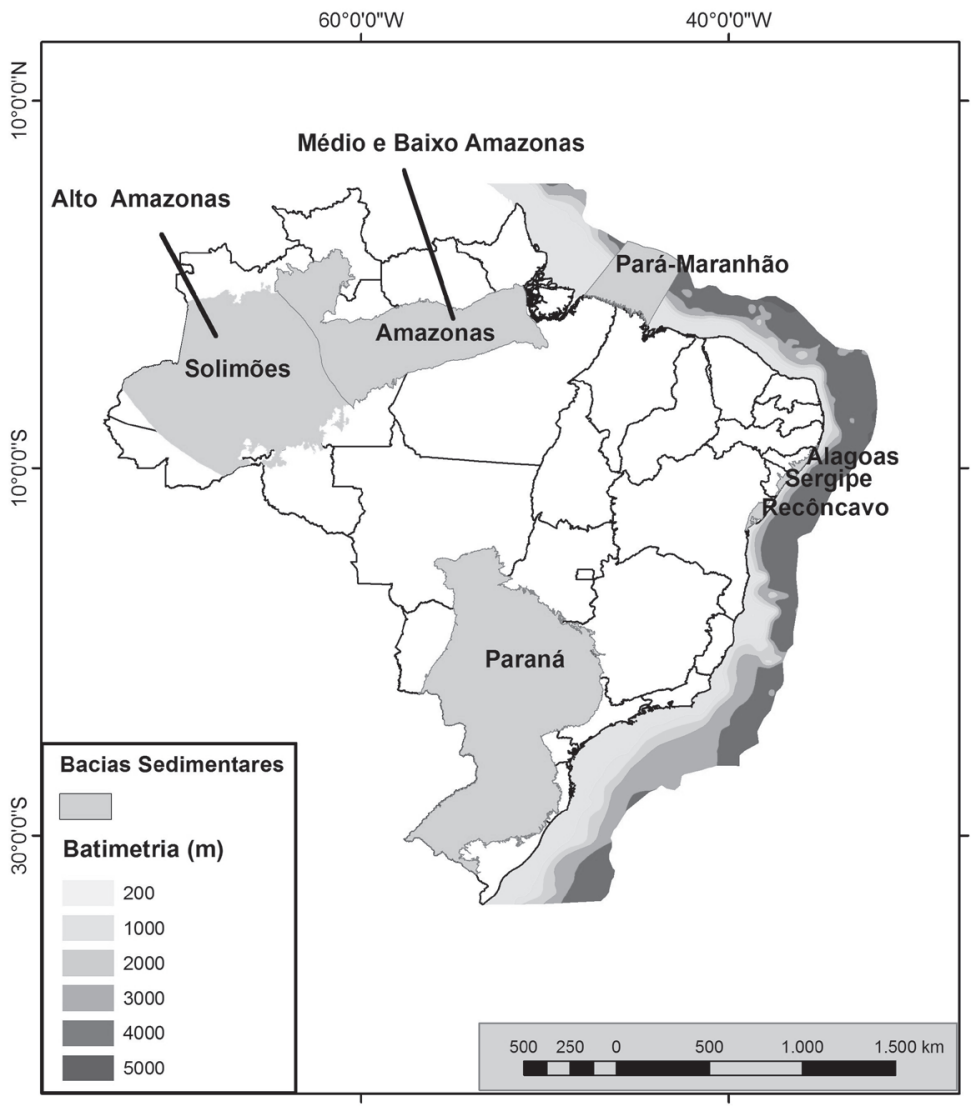

MAPA 3. Perfurações exploratórias realizadas nas bacias sedimentares brasileiras pelo DEPEX - 1961 Fonte: elaborado pela autora 


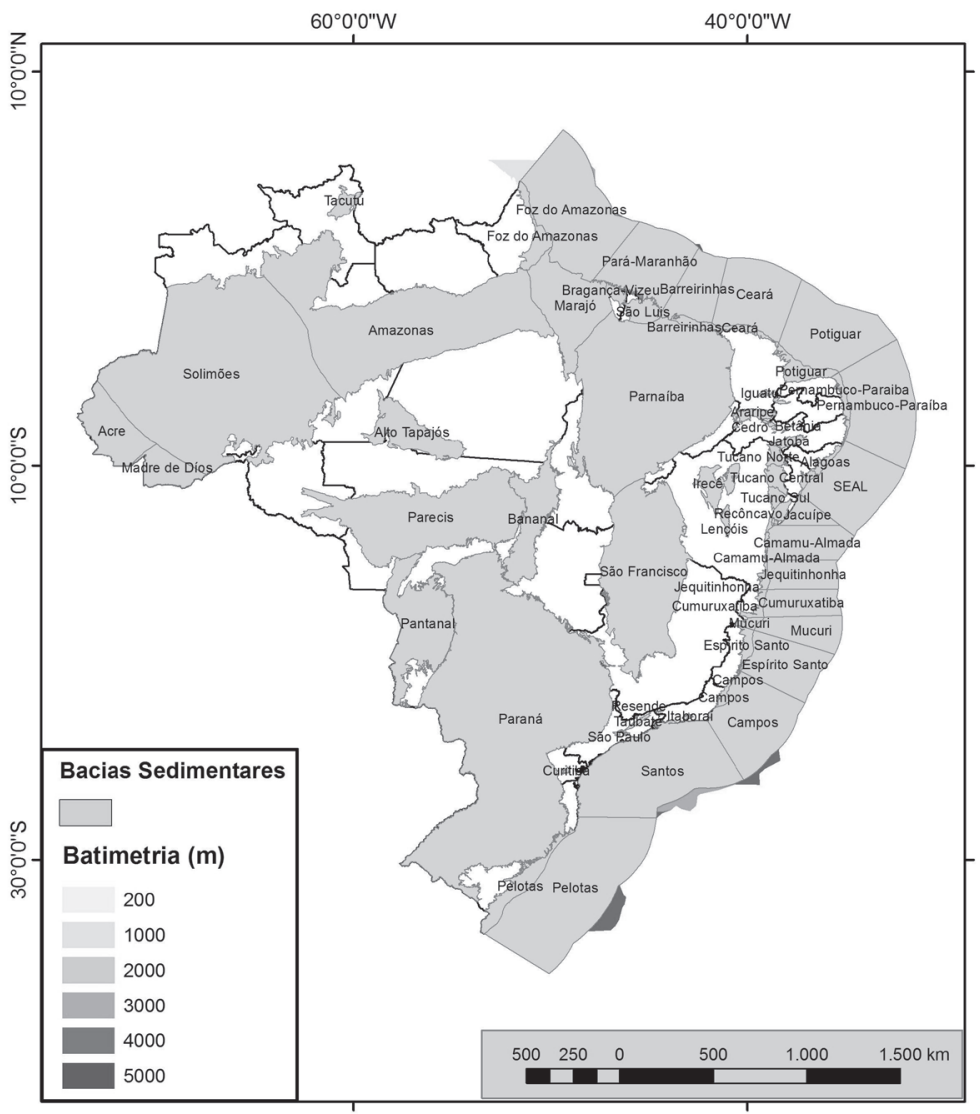

MAPA 4. Bacias sedimentares brasileiras atuais

Fonte: elaborado pela autora

As principais técnicas utilizadas nas bacias sedimentares, nesse período, relacionavam-se ao método sísmico, "principalmente os de refração de baixa frequência, trabalhos geofísicos êsses associados ou complementados por perfurações estratigráficas profundas" que fornecem elementos precisos para a interpretação dos perfis sísmicos (LANGE, 1961, 
p. 20). 0 emprego do método sísmico, principalmente na Bacia do Recôncavo, gerou bons resultados em conjunto com sondagens estruturais e por correlação palinológica (LANGE, 1961).

Devido ao conjunto de fatores mencionados, e para compreendermos o trabalho conjunto de estrangeiros e brasileiros dentro do Departamento de Exploração da Petrobras para formação do know-how, elaboramos gráficos ${ }^{108}$ para melhor visualização desse trabalho em 1961, ano em que encerramos a segunda parte deste livro e em que ocorre uma reestruturação do DEPEX, uma maior formação de profissionais brasileiros e o encerramento de contratos com vários técnicos estrangeiros. Assim, ocorre uma reavaliação do potencial técnico de que dispunha o departamento.

Os Gráficos 02 a 05 representam o trabalho dentro do DEPEX, por Bacia analisada, especificamente nas áreas de geologia e de paleontologia. Os Gráficos 06 e 09 representam bem a tática adotada pela Petrobras para treinar brasileiros a fim de, futuramente, substituir os estrangeiros. Os Gráficos 10 e 11 retratam o mesmo caso, mas na área da paleontologia, e os Gráficos 12 e 13, na área de palinologia (utilizamos o termo da época, "palinologistas", substituído por "palinólogos"). Para finalizar, elaboramos o Gráfico 14, que indica os países a que pertenciam os estrangeiros que trabalhavam na Petrobras, em 1961, e que possivelmente já estavam há mais de dois anos no país, demonstrando-se, assim, a variedade de importações técnicas que tivemos para a formação do know-how do petróleo.

\footnotetext{
${ }_{108}$ Os Gráficos 2 a 14 foram elaborados pela autora a partir de dados analisados e compilados do relatório denominado "Organização regional e situação dos técnicos do Departamento de Exploração", assinado por Frederico Waldemar Lange, em 1961.
} 


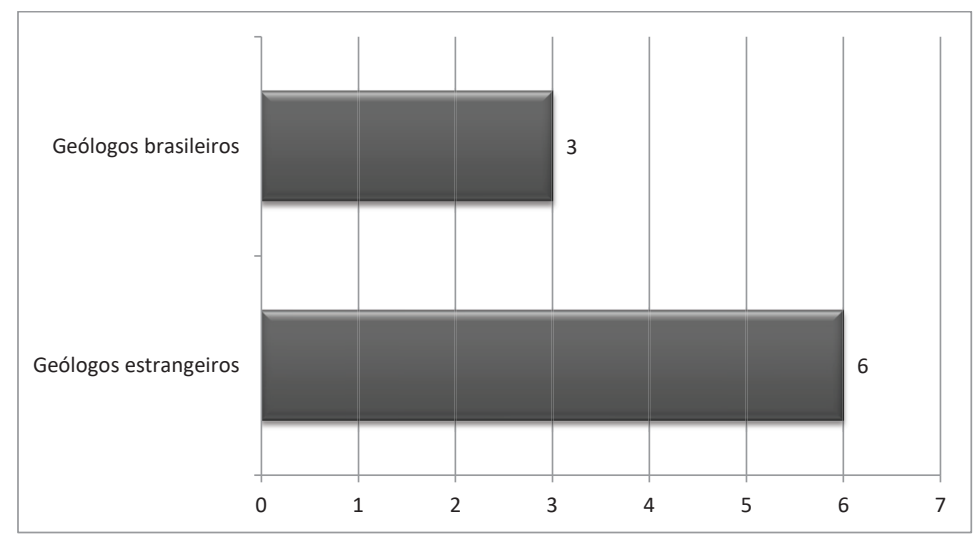

GRÁFICO 2. Bacia do Paraná (geólogos) - 1961

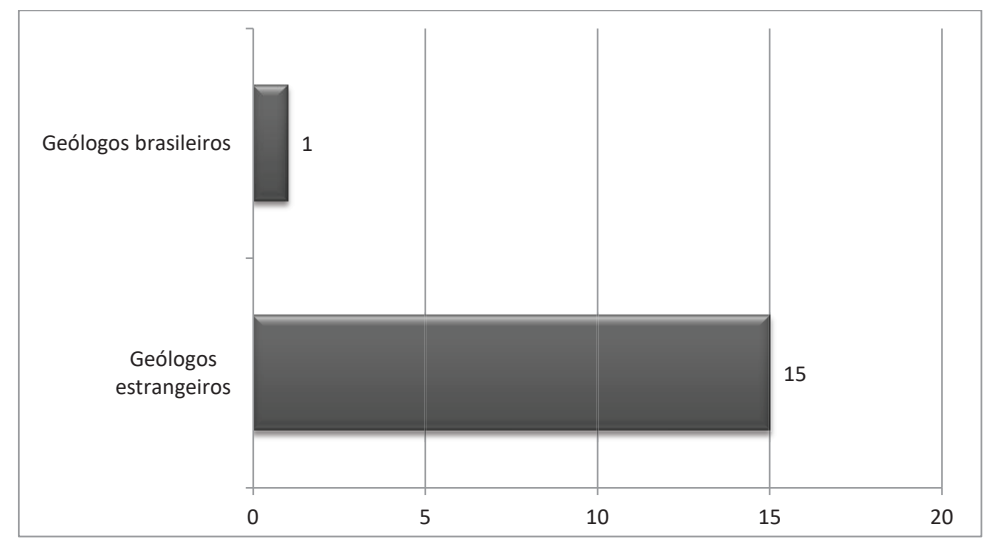

GRÁFICO 3. Bacia do Amazonas/Maranhão (geólogos) - 1961 


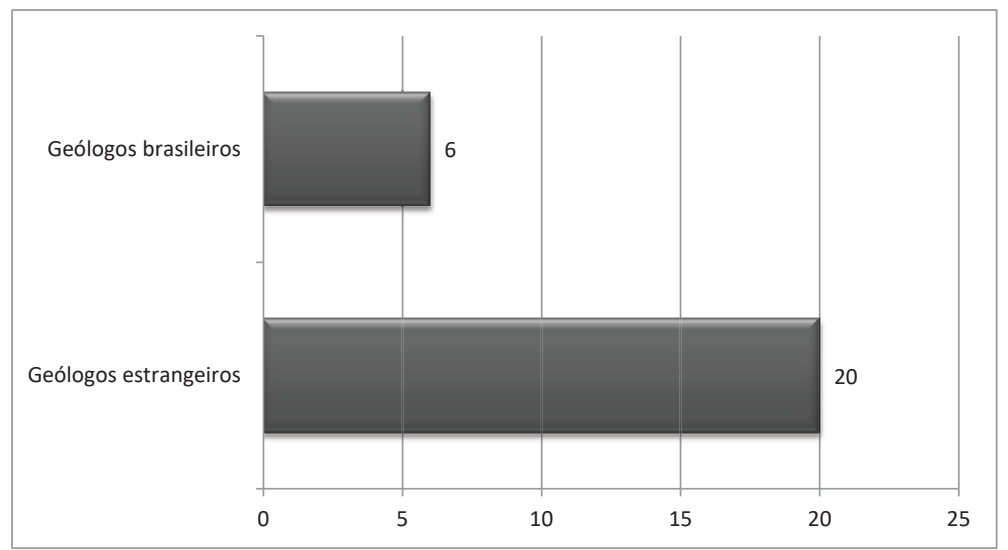

GRÁFICO 4. Bacia do Recôncavo (geólogos) - 1961

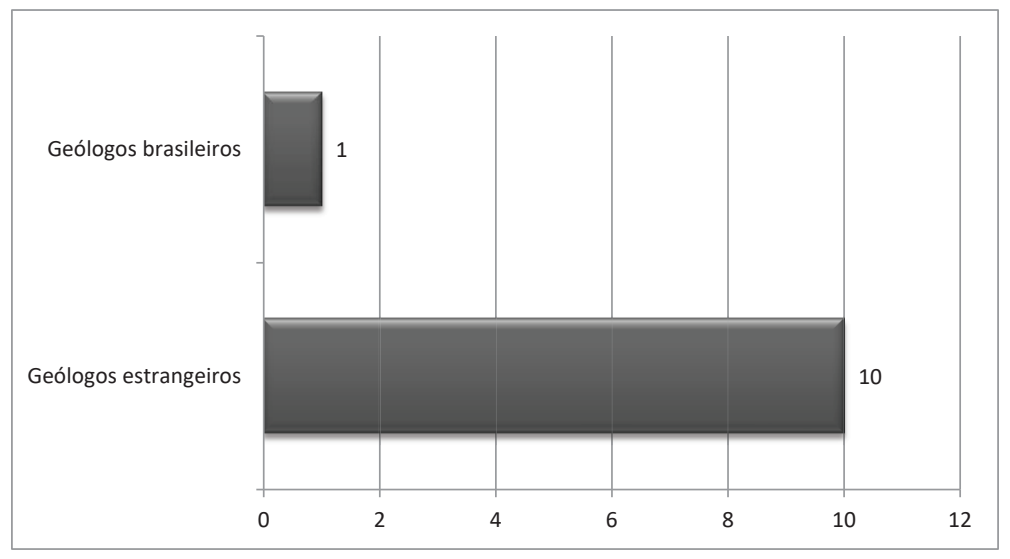

GRÁFICO 5. Bacia Sergipe/Alagoas

(geólogos) - 1961 


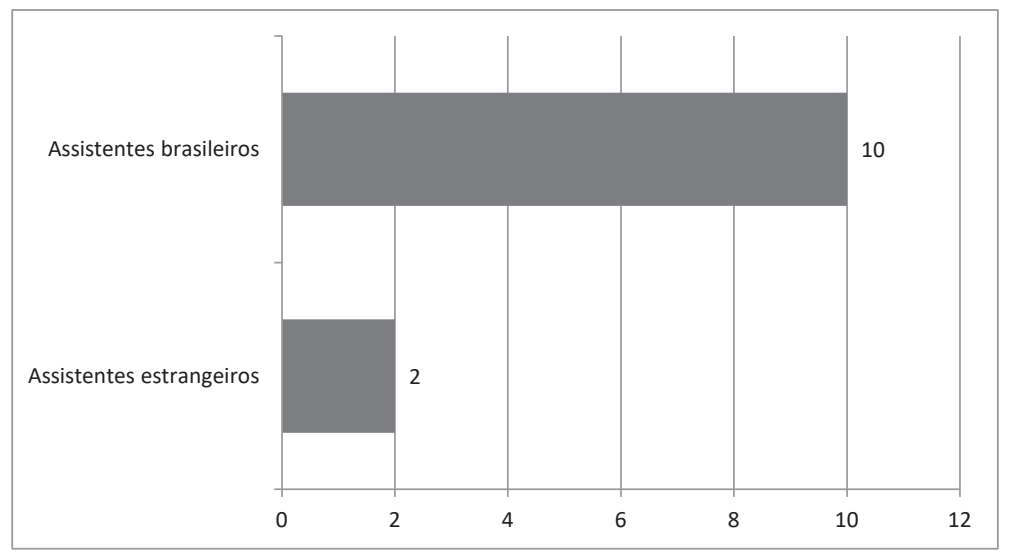

GRÁFICO 6. Bacia do Paraná

(assistentes de geologia) - 1961

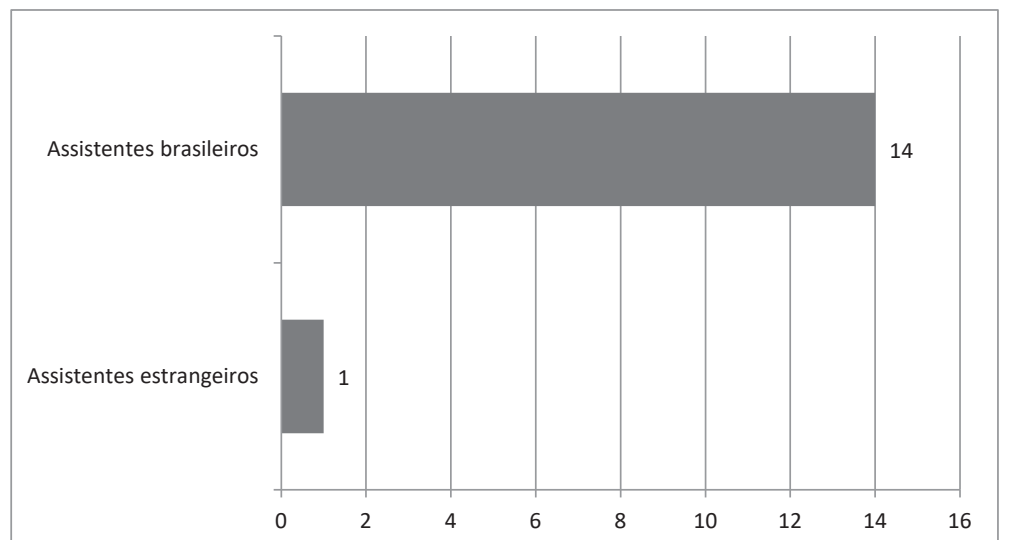

GRÁFICO 7. Bacia do Amazonas/Maranhão

(assistentes de geologia) - 1961 


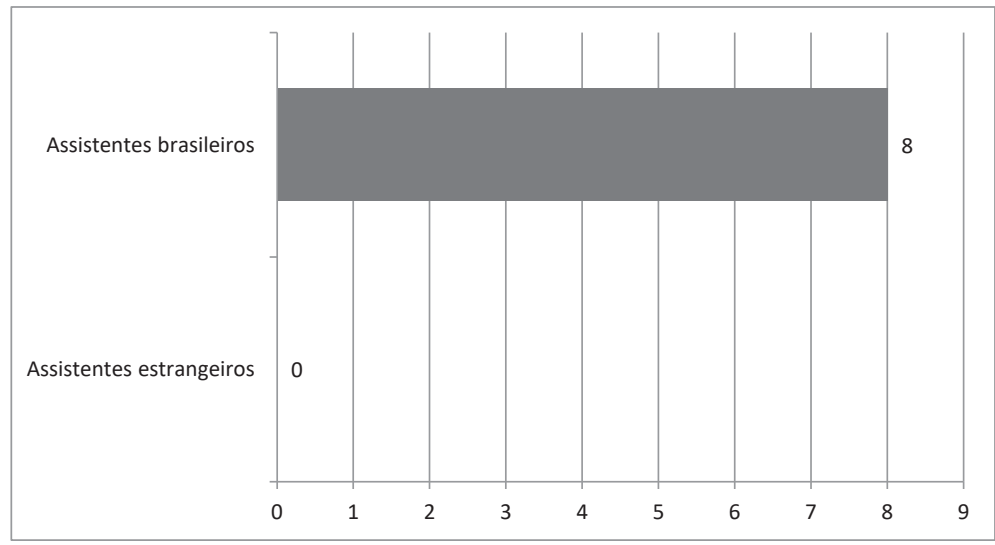

GRÁFICO 8. Bacia do Recôncavo

(assistentes de geologia) - 1961

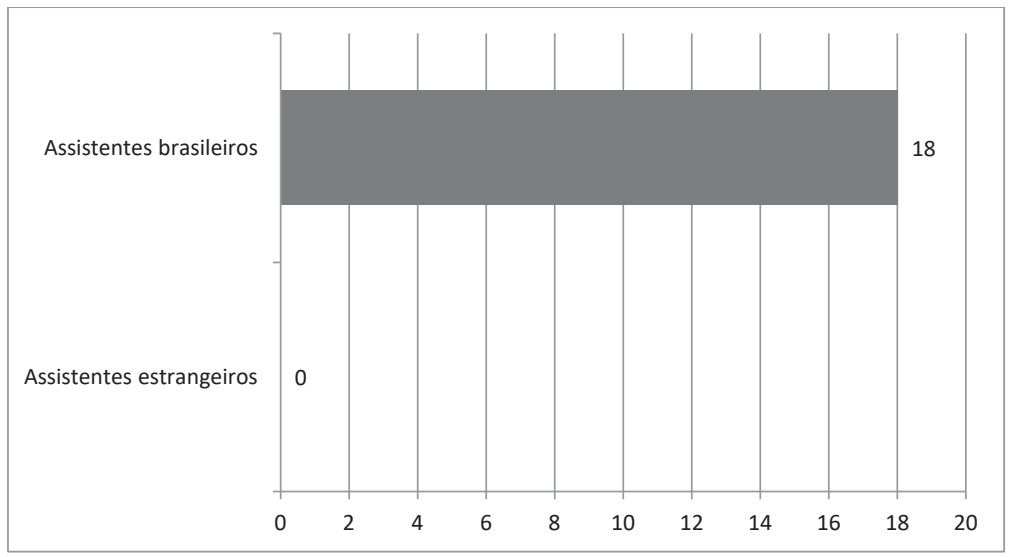

GRÁFICO 9. Bacia Sergipe/Alagoas

(assistentes de geologia) - 1961 


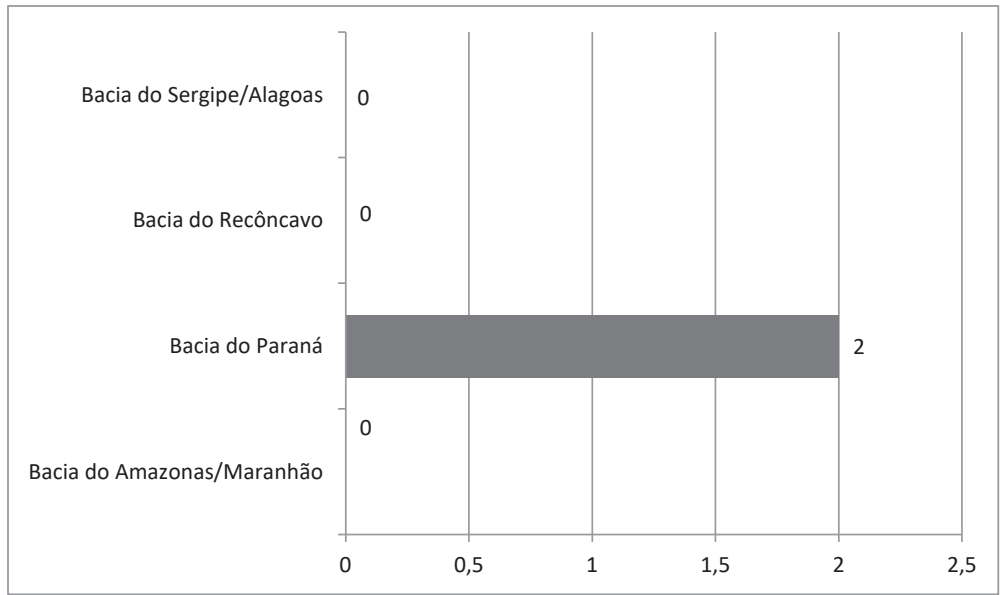

GRÁFICO 10. Paleontólogos brasileiros - 1961

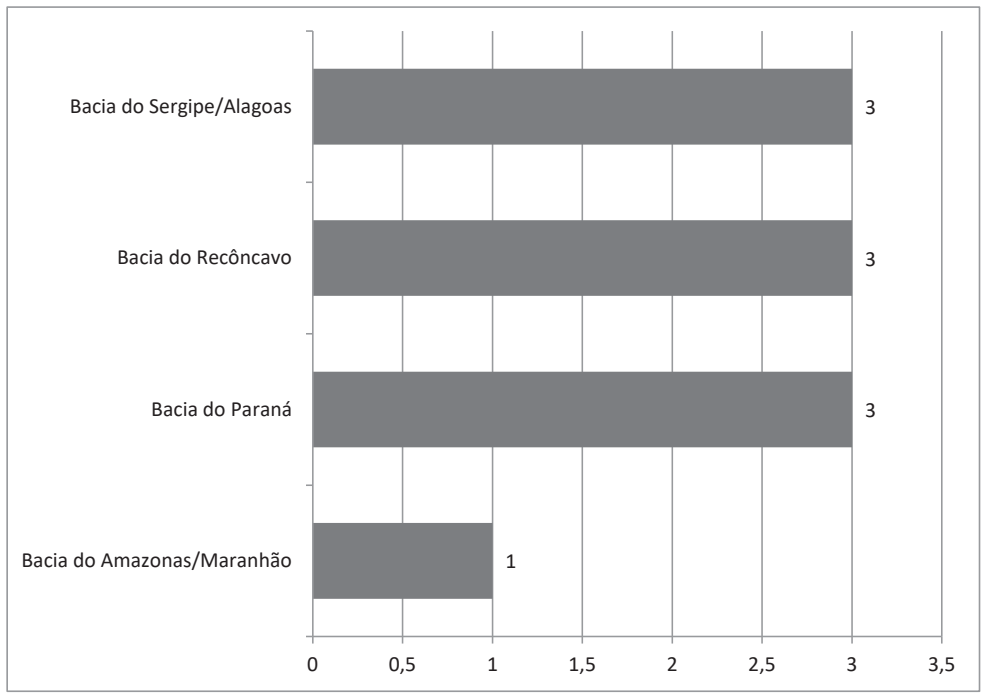

GRÁFICO 11. Assistentes de paleontologia - 1961 


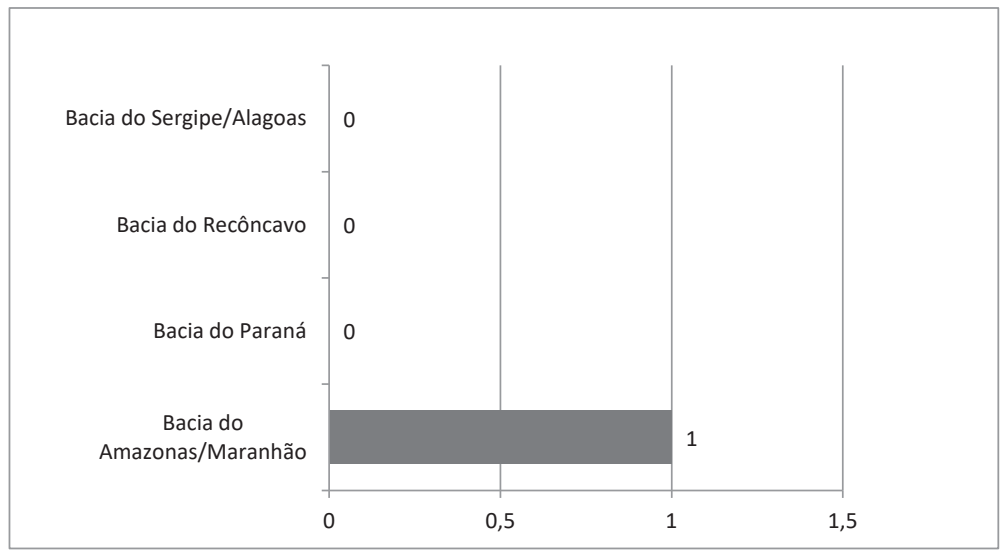

GRÁFICO 12. Palinologistas - 1961

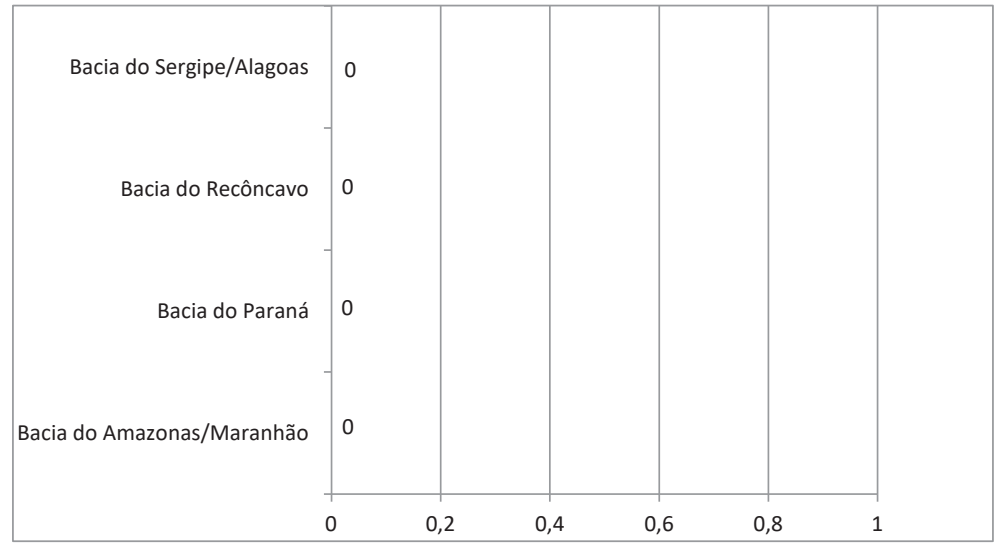

GRÁFICO 13. Assistentes de palinologia - 1961 


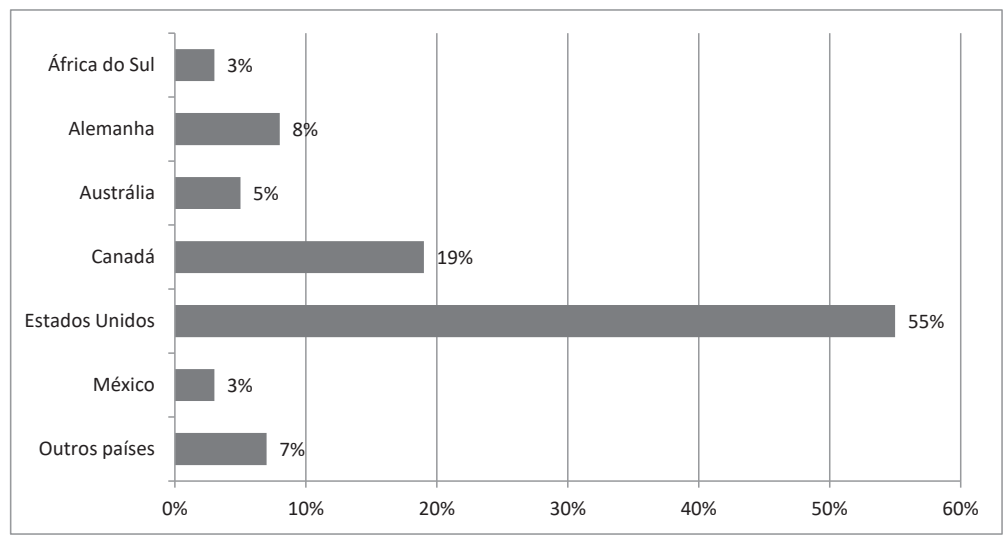

GRÁFICO 14. Países de formação dos geólogos estrangeiros ${ }^{109-110}$

109 Salientamos que a maioria dos geólogos formados nos Estados Unidos pertenciam às seguintes Universidades, entre outras: University of California, University of Arkansas, University of Nebraska, Columbia University e University of Texas. A porcentagem de 7\% pertence a países como Inglaterra, Polônia, França e outros.

${ }^{110}$ Esses gráficos demonstram que o corpo de trabalhadores da Petrobras começou a se formar, em sua maioria, por brasileiros. Salientamos que um maior entendimento de como o CNP e a Petrobras trabalharam para conseguir formar seu quadro de profissionais, item de destaque deste livro, encontra-se no terceiro capítulo. Os gráficos ainda demonstram dados concretos da Petrobras concernentes à utilização do trabalho de estrangeiros para a aprendizagem dos brasileiros, pois nota-se um maior número de assistentes de geologia brasileiros em comparação ao de geólogos estrangeiros trabalhando no país. 